\title{
LEGAL ASPECTS OF ISLAMIC BANKING AND FINANCE IN NIGERIA
}

\author{
Muhammad Bashir Alkali ${ }^{1}$ \\ Ahmad Hidayat Buang ${ }^{2}$
}

\begin{abstract}
Whether or not they are considered spiritual or mundane, laws which govern every aspect of human affairs in Nigeria, especially in regards to Islamic Banking and Financial institutions, exist owing to the plural legal system in the country, these aspects of society are regulated by both the Islamic and statutory laws imposed by the former British colonizers. Various legal sources, including the Qur'ān, the hadìth, constitution, Banks and Other Financial Institutions Act, Central Bank Act, and Nigerian Deposits Insurance Corporation Act constitute its regulatory framework. This work intends to analyze the said laws with the objective of identifying and filling the lacunae therein, in order to forestall future legal obstacles to the system. This study therefore analyses this convoluted legal hybridity and suggests ways of overcoming any obstacles. The methodology utilized in this research is that of literature review. This study concludes with the suggestion that the said obstacles may be overcome through more emphasis on the use of religious legislation, amendments to the constitution, and a new legislation.
\end{abstract}

\footnotetext{
1 Ph.D Candidate, Department of Shariah and Law, Academy of Islamic Studies, University of Malaya, 50603 Kuala Lumpur, mbashiralkali@yahoo.com

2 Professor, Department of Shariah and Law, Academy of Islamic Studies, University of Malaya, 50603 Kuala Lumpur, ahidayat@um.edu.my
} 
Keywords: Islamic Banking and Finance (IBF), Islamic Law, Nigerian Constitutional Lacunae, BOFIA 1991, NDIC Act 2006, CBN Act 2007

\section{INTRODUCTION}

Nigerian citizens ${ }^{3}$ were independent from any world super-power before the arrival of the British colonialists. ${ }^{4}$ The nature of these administrations varied; some of the communities operated under organized leadership while some were not well organized though they equally had chains of leadership. ${ }^{5}$ The Kanem-Borno Empire ${ }^{6}$ and Sokoto Caliphate, ${ }^{7}$ both in the Northern region, have had chains of formally organized and rigid systems of administration, which were based on mostly hereditary rule and assisted by military lieutenants who acted on behalf of their Muslim leaders. ${ }^{8}$ The Empires also functioned based off the Shariah legal system. Historically, as far back as the $11^{\text {th }}$ century,

3 Nigeria is the richest West African nation with the largest concentration of black Africans in the world. Over $50 \%$ of its 170 million populations are Muslims and the rest are $40 \%$ Christians and 5\% atheists. It is nicknamed the 'Giant of Africa'. Sampson I. T., 'Religion and the Nigerian State: Situating the de facto and de jure Frontiers of State-Religion Relations and its Implications for National Security,' Oxford Journal of Law and Religion, 3/2 (2014): 311-339; Muhammad, L. A. \& Atte O. A., 'An Analysis of Agricultural Production in Nigeria,' African Journal of General Agriculture African Studies on Population and Health, 2/1 (2006); Okolo C. B., Squander Mania Mentality: Reflections on Nigerian Culture (Nsukka: University Trust Publishers, 1994), 1; Abdullahi, S. I., 'Islamic Banking in West African Sub-Region: A Survey,' Arabian Journal of Business and Management Review (OMAN Chapter), 2/7 (2013); The Economist Magazine, 'Nigeria's Moment,' The Economist Magazine, $20^{\text {th }}$ June 2015, 11.

4 Falola T. \& Heaton M., A History of Nigeria (Cambridge: Cambridge University Press, 2008).

5 Tobi, N., Sources of Nigerian Law (Lagos: M.J. Professional Publishers Ltd., 1996), 1.

6 Collins R. O., 'Kanem: Decline and Merger with Borno (c. 1400),' Encyclopedia of African History, ed. Kevin Shillington (New York: Fitzroy Dearborn, 2005).

7 Last M., The Sokoto Caliphate (London: Longmans, Green and Co, 1967).

8 Like the Mainin Kinandi (second to the king in all arms of Kanem-Borno Government), Waziri (Prime Minister), Shettima (Sclolar/Head of Unit) etc. ElYakub, K., 'An Auto-Ethnographical Study of Integration of Kanuri Traditional Health Practices into the Borno State Health Care System,' (Ph.D. Thesis, Durham University, 2009), 52; Naniya, T. M., 'Arab Settlers in Sub-Saharan Africa: A Survey of their Influence on Some Central Sudanese States,' A Journal of Savanna \& Sudanic Research, 1/1 (2000). 
Islamic law was practiced in many parts of today's Nigeria, like Iwo, Ikirun, Ede, Ilorin, Kano, Borno, Katsina, and Etsako Division Auchi and Okpella of Edo State. Between 1804 and 1900, Shariah was practiced in each of these territories, either as the law of the state or applied to local communities within the regions. ${ }^{9}$

Islam came to Nigeria through the Kanuri people of the Kanem-Borno Empire, and consequently, so did the Shariah (Islamic Law). It is believed that the Arab merchants brought Islam to Borno. Mai Humme Jilme (10851097 C. E.) was the first Mai (king) of Borno to embrace Islam ${ }^{10}$ resulting in the spread of the religion throughout the whole of the kingdom. ${ }^{11}$ Though the people of Hausa embraced Islam around 1797, ${ }^{12}$ it was practiced synthetically with their traditional religion. Later, Shehu Usman Dan Fodio (1754-1817) waged a physical jihād (war) against the Hausa rulers and established Islamic law throughout his land. ${ }^{13}$ This positively impacted the establishment of Islam throughout the region, making it dominant and paving the way towards the establishment of the Shariah legal and commercial systems.

In a similar vein, the Western part of Nigeria is predominantly populated by the Yoruba speaking ethnic majority who are also Muslims. Just like their counterparts in the Northern part of the country, the Yoruba people have a leadership structure under the so-called Oba. The structure of the society is primarily patriarchal. Customs and traditions were respected and put to practice in the administration of government and judiciary. ${ }^{14}$ It is believed that Islam reached Yoruba close to the $18^{\text {th }}$ Century. Although Islamic law was not fully implemented, Muslims practice their religion with little to no challenges. ${ }^{15}$ However, religious scholars did settle in Yoruba by 1830 through

\footnotetext{
9 Abdullah, U. Y., Sharia in Africa (Ijebu-Ode: Shebiotimo Publication, 1998), 8384.

10 Meek, C. K., The Northern Tribes of Nigeria, vol. 2 (London: Frank Cass, 1971), 262.

11 Naniya, T. M., 'Arab Settlers in Sub-Saharan Africa: A Survey of their Influence on Some Central Sudanese States,' 6.

12 Balogun, A. B., The Life and Works of Uthman dan Fodio The Muslim Reformer of West Africa (Lagos, Nigeria: Islamic Publications Bureau, 1975), 98.

13 Naniya, T. M., 'Arab Settlers in Sub-Saharan Africa: A Survey of their Influence on Some Central Sudanese States,' 6.

14 Tobi, N., Sources of Nigerian Law, 1.

15 Fafunwa, A.B., History of Education in Nigeria (UK: George Allen and Unwin Ltd., 1979), 57.
} 
Ilorin (a Yoruba city in Northern Nigeria). ${ }^{16}$ Muslims constitute the majority population in Yoruba up to this date. ${ }^{17}$ However, when Christian missionaries arrived in the South Western part of Nigeria in the $18^{\text {th }}$ Century, their activities in the region significantly resulted in slowing the pace of the spread of Islam.

Islam reached the South Eastern part of the country much later following the jihād of Sheikh Usman Dan Fodio. ${ }^{18}$ The British colonialists amalgamated the Northern and Southern Protectorates in 1914 and named it Nigeria resulting in the belittling of Islamic law to the status of customary law which was hitherto fully implemented in both the Kanem Borno and the Sokoto empires. The colonialists gradually stopped the implementation of Islamic Criminal law by subjecting it to validity tests (also called repugnancy test). ${ }^{19}$ Finally, the Penal Code was passed into law with only a passing appeal to Islam and this expressly put an end to the regime of the application of Islamic criminal law in Nigeria thus negatively impacting on the jurisdictions of the Shariah Courts by circumscribing it to family matters and some criminal cases only. For example, the Nigerian Sharia Court of Appeal has jurisdiction on domestic issues and disputes only. ${ }^{20}$ However, Islamic law of personal status continues to apply. ${ }^{21}$ This Nigerian situation is identical to that of Malaysia as clearly stated by Buang, A. H.:

16 Fafunwa, A.B., History of Education in Nigeria, 57. Like Ahmad Qifu and Uthman bin Abubakar who came to Ilorin during the reign of Oluyedun and established large Islamic schools.

17 Fafunwa, A.B., History of Education in Nigeria, 57. Idol worship is still found in most parts of the South Western part of the country. Unfortunately Muslims also participate or combine idol worship with Islam; for example the worship of Osun deity.

18 Shehu Usman Dan Fodio, a Fulani by tribe, was the leader of the Sokoto Caliphate. He led the Sokoto jihād on the Hausa emirs of Northern Nigeria and succeeded in establishing an Islamic state in most part of Northern Nigeria. Akínlàdé, K., Shehu Usman dan Fodio (Ibadan: Onibonoje Publishers, 1979).

19 The Native Court Ordinance explicitly mentioned that Islamic Law is the same as customary law. The implication of this provision is that before Islamic law applies, it must not be repugnant to natural justice, equity, and good conscience in accordance with customary law.

20 Section 262 (1) of the 1999 Nigerian constitution provides: "The Sharia Court of Appeal shall, in addition to such other jurisdiction as may be conferred upon it by an Act of the National Assembly, exercise such appellate and supervisory jurisdiction in civil proceedings involving questions of Islamic personal law..."

21 Tobi, N., Sources of Nigerian Law, 42. 
"With western and European colonization of Muslim lands, the practice of Islamic Shariah is in many areas reduced to family matters. " 22

IBF in Nigeria came at a time when a greater percentage of Muslims in Nigeria were clamoring for the establishment of banking and finance system free from riba and other forms of business transactions unacceptable under Islamic law. This effort by Nigerian Muslims could have been the result of what Buang, A. H. described as "Muslims' efforts to avoid social decay by being indifferent to IBF by themselves". ${ }^{23}$

\section{LEGAL HISTORY OF BANKING AND FINANCE IN NIGERIA}

Since the pre-colonial Sokoto caliphate of Nigeria, various forms of money lending have been practiced since $1903 .{ }^{24} \mathrm{~A}$ case was reported of a successful Hausa businessman in the 1930-40s, Alhaji Al Hasan, who used to tactically gain from lending money from bank interests from his savings account and simultaneously avoided usury. He advanced money to the young men of sound business acumen and required them to pay him half of their business profit, or less at times, if no profit was made. When he eventually invested with conventional banks, he was reported to have refused interest for religious reasons though he accepted customer gifts at the end of the year. ${ }^{25}$

Usury was prohibited in other parts of pre-colonial Nigeria. The Zanna Ballama was the head of the treasury (Bayt al-Mâl) in the Kanem Borno Empire (also called the Sefawa Dynasty), now called Borno State in Nigeria. Usury was prohibited in the government as it had been run by the King (Mai) under Islamic Law since the $9^{\text {th }}$ Century. ${ }^{26}$ However, modern banking was not introduced in the region until 1894.

22 Buang, A. H., 'Islamic Contracts in a Secular Court Setting: Lessons from Malaysia,' Arab Law Quarterly, 21 (2007): 317-340, 318.

23 Buang, A. H., 'Islamic Contracts in a Secular Court Setting: Lessons from Malaysia,' 317.

24 AbdulQadir Abikan, 'Constitutionality of Islamic Banking in Nigeria,' in Contemporary Jurisprudence in Islamic Jurisprudence (Benin: Rawel Fortune Resources, 2009).

25 AbdulQadir Abikan, 'Constitutionality of Islamic Banking in Nigeria.'

26 Collins R. O., 'Kanem: Decline and Merger with Borno (c. 1400)'; Naniya, T. M., 'Arab Settlers in Sub-Saharan Africa: A Survey of their Influence on Some Central Sudanese States.' 
In 1894 the Bank of British West Africa (BBWA) was established. It was later known as Standard Bank and is presently known as First Bank of Nigeria. The Bank of Nigeria - initially called The Anglo African Bank - was established in $1899 .{ }^{27}$ Banking legislation commenced after the amalgamation of the three colonial protectorates of the area into one nation (i.e. Nigeria).

Thus, in 1952, the first Banking Ordinance was promulgated which resulted in protests by nationalists against the supposed domination by foreigners of the banking industry. The Central Bank of Nigeria Ordinance and Banking Act of 1958 were also enacted. The Central Bank of Nigeria Decree No. 24 and the Bank and other Financial Institution Decree No. 25 were enacted by 1991. The thrust of these laws was to control the new banks and other financial institutions emerging as a result of the 1987 financial liberalization and deregulation. ${ }^{28}$ No mention was made of IB until the coming into force of the Banks and other Financial Institutions Decree No. 25 (there will be more discussions on this later under the legal frameworks of IBF) following the pressing demand by Muslims to have banks that comply with the principles of Shariah. Habib Bank attempted to open a window of non-interest banking, but that commendable effort fell short of achieving the expected result.

The Central Bank, on $11^{\text {th }}$ September, 2011, issued a license to Jaiz Bank $\mathrm{PLC}^{29}$ to operate a Shariah compliant banking business in Nigeria. It was hoped that with the unprecedented patronage and support the new Jaiz Bank is enjoying it will remain despite the Abuja High Court decision in 2002 declaring it illegal (although it did not withdraw its license). Most Nigerian authors see the defunct Habib Nigeria Bank Ltd as the first Islamic variantbanking model because it opened the first window for non-interest banking while Jaiz International PLC is regarded as the trend setter for a full-fledged Islamic Bank in Nigeria. ${ }^{30}$

27 Chibuike Uche, 'The Economic History Review,' New Series, 52/4 (1999): 669691.

28 AbdulQadir Abikan, 'Constitutionality of Islamic Banking in Nigeria.'

29 Wikipedia, 'Jaiz Bank Plc., Nigeria,' Wikipedia, http://en.wikipedia.org/wiki/Jaiz Bank, 5th January 2017.

30 Abubakar S. Orisankoko, 'Socio-Economic and Legal Challenges of ShariaCompliant Banking Operation, its Developmental Impacts and the Struggles of the Believers: Epistemological Lessons from Nigeria,' Journal of Islamic Economics, Banking and Finance, vol. 8 46/2 (2012): 49. 
The Central Bank of Nigeria is the body mandated by law to issue licenses for the operation of all banking services in Nigeria. The promulgation of the Central Bank of Nigeria (CBN) Act 2007 and the Banks and Other Financial Institutions Act (BOFIA) was indeed a landmark development in the effort to confer some measures of autonomy on the CBN to effectively carry out its core mandate. But the financial system continued to witness rapid reforms and developments which challenged the legal framework of the CBN. Significant of such developments are the transfer of the supervision of specialized banks to the $\mathrm{CBN}$, the global war on economic crimes, unprecedented bank failures associated with weak internal controls, reform of the banking industry and the entire economy, and the adoption of Universal Banking in the country. ${ }^{31}$ These developments have made a complete review of the existing legal framework necessary. For instance, new measures were proposed for strengthening the CBN which became embodied in the CBN Act of $2007 .^{32}$

The Central Bank of Nigeria Act, 2007 signaled a new era of economic reforms in Nigeria. It gave more autonomy to the $\mathrm{CBN}$ in carrying out its financial regulatory functions according to international standard practices. One of such functions is the supervision and regulation of the non-interest banks (NIB) in Nigeria. It is noteworthy that the provisions in the CBN Act 2007 and the BOFIA have laid a legal foundation for non-interest banking in Nigeria. It is in pursuance of this that the Bank issued certain guidelines pursuant to some relevant provisions in the CBN Act 2007 and the BOFIA. The former provides:

"In addition to any of its powers under this Act, the Bank may... issue guidelines to any person and institution under its supervision." 33

Based on the aforementioned, the CBN issued a draft framework for the regulation and supervision of non-interest banks in Nigeria on March 4th, $2009 .{ }^{34}$ Consequently, the Jaiz bank was licensed based on this guideline, but the draft was not developed to become an IB Act as obtained in Malaysia which was later replaced by the Financial Services Act (FSA) 2013 of Malaysia. ${ }^{35}$ The Act regulate Islamic Banking and Finance aspects in the country. This was

\footnotetext{
31 Central Bank of Nigeria (CBN) (2011). Legal Services Department.

32 Dauda, M., 'Legal Framework for Islamic Banking and Finance in Nigeria,' Journal of Islamic and Middle Eastern Law (EJIMEL), 1/7 (2013): 161.

33 Section 33(1) (b) of the CBN Act 2007.

34 Central Bank of Nigeria (CBN) (2011).

35 Formerly Islamic Banking Act 1983 and Takaful Act of Malaysia.
} 
in response to the increasing number of investors as well as banks and other financial institutions desiring to offer non-interest products and services. ${ }^{36}$

\section{LEGAL FRAMEWORKS OF IBF IN NIGERIA}

Although this is not a comparative study, it is relevant to see the development of the system from its source. There is no special and separate law for IBF in Nigeria like the Financial Services Act (FSA) 2013 (formerly Islamic Banking Act 1983 and Takaful Act) of Malaysia. ${ }^{37}$ It was enacted on the recommendation of the National Steering Committee to regulate IB by modifying the Banking Act of Malaysia to the effect that,

Firstly, there must be a Religious Supervisory Council (RSC) consisting of three to seven Muslim Religious Scholars (MRS) to advise the Bank on compliance. Secondly, the Bank must comply with not only Islamic law, but equally the governmental legal framework like the Contracts Act 1950 and the Bills of Exchange Act 1949. Thirdly, all documents and instruments used in the Banking transactions must be structured in such a way as to be enforceable in the civil courts (same as in Nigeria). ${ }^{38}$

There are three other Malaysian legislations regulating IBF operations vis-à-vis the FSA: First, the Government Investment Act (GIA) 1983 was enacted to enable IB to invest in non-interest bearing Government Investment Certificates (GIS); also known as interbank market. ${ }^{39}$ Second, the Banking and Finance Investment Act enables non-Islamic Banks to operate IB Windows under the IB Scheme (IBS). Third, The Central Bank National Shariah Advisory Council (CBNSAC) Act 1997 makes the IB Shariah advisors subordinate to the CBNSAC which is the sole supreme advisory authority on IB and Takaful. ${ }^{40}$

Similar to the Malaysian Central Bank National Shariah Advisory Council (CBNSAC), the Central Bank of Nigeria (CBN) inaugurated an Advisory Council of Experts on Islamic Banking and Finance. This council supervises

\footnotetext{
36 Dauda, M., 'Legal Framework for Islamic Banking and Finance in Nigeria, '164.

37 Islamic Banking Act 1983 (Act number 276 of 1983).

38 Islamic Banking Act 1983 (Act number 276 of 1983).

39 Naighton, S., \& Shammugan, B., 'Interest Free Banking: A Case Study of Malaysia,' Journal of IBF, 7/3 (1990): 46.

40 Hasani, I., 'Theory and Practice of Islamic Banking in Malaysia and its Implementation in Kosovo,' (PhD Thesis, Department of Shariah and Economics, Academy of Islamic Studies, University of Malaya, 2009), 142.
} 
all Islamic financial issues regulated by the CBN, Securities and Exchange Commission (SEC), Ministry of Finance (MoF), Capital Market, etc.

In Nigeria, the laws which deal with IBF are many; some deal directly with the operation and structure of the banking system, while others-though not directly in touch with operations of the system-drive their validity through them. An example of this is Section 315 of the Nigerian Constitution, 1999 which brings all laws predating the Constitution under its ambit and deem them as having been properly made under it. Thus, virtually all the laws regulating banking and finance practice in Nigeria fall within this category.

The sources of law for IBF in Nigeria are as follows:

\section{Islamic Law}

By definition Islamic law is the natural order established by Allah for mankind to achieve balance, justice, and equity; not only for human beings, but for all things created by Allah, material and non-material. ${ }^{41}$ It is a whole system that does not give room for selective appreciation. ${ }^{42}$

The aim of Shariah is to use truth in arriving at justice through the progressive use of the rules and principles of adjudication. ${ }^{43}$ The Shariah conceives human life in its totality and as such gives guidance in all aspects of human endeavors so as to enhance worship. It is therefore more a code of religious duties in every aspect of private and public field which guarantees its authority and the unity of Muslims despite their great diversity. ${ }^{44}$ Accordingly, there are rules and regulations for all business transactions in the Shariah. ${ }^{45}$

${ }_{41}$ Imam I., et al., 'The Unending Crises on the Status of Sharia in Nigeria: A Critical Analysis,' Usman Danfodio University Sokoto Journal of Islamic Comparative Law (UDUSJICL), 2 (2010): 116.

42 Imam I., et al., 'The Unending Crises on the Status of Sharia in Nigeria: A Critical Analysis,' 116.

43 Gafai I.A., 'Comparative Analysis of the Rights of Women in Sharia and Common Law in Contemporary Nigeria,' Journal of Islamic Science and Contemporary Development, 2 (2010): 30.

44 Madupe A.N. et al., 'The Economic Right of Women under Islamic Law: the Obstacles and Challenges in Contemporary Nigeria,' Human Rights Review, 3 (2012): 120.

45 Muhammad M.A., 500 Questions and Answers on Islamic Jurisprudence, ed. Reima Y, Shakeir (Lahore: Dar al-Manara, 2006), 383-368. 
Since the IBF operates on the Islamic principles of profit and loss sharing, avoidance of unlawful or forbidden items such as wine, pigs, corpse, human blood, and riba, a Muslim is enjoined to refrain himself from these things so as to avoid Allah's wrath. As a result, he or she will be rewarded by the Almighty for his transactions in lawful acts. ${ }^{46}$

The three main sources of law for IBF in the Shariah perspective are as follows:

\section{a) The Qur'ān:}

The Qur'ān states:

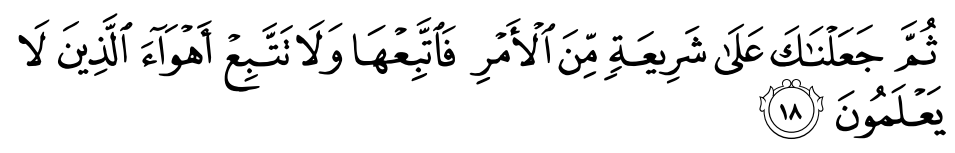

"We have made for you a law (Shariah) so follow it and not the fancies of those who have no knowledge."

(Surah al-Jāthiyah, 45: 18)

The above verse testifies to the fact that the Qur'ann is the manual for successful human activities including IBF operations (as the Qur'ān prohibits gambling, speculative investments and usury). Hence, the survival of IBF institutions in the West during the global economic crises. For instance, the 2007-2010 Credit crisis of USA, also known as subprime mortgage crisis was one of the main indicators of the global fiscal crisis of that time. A credit crisis, also known as a credit crunch, is commonly referred to as "severe shortage of money or credit in the economy." " ${ }^{47}$ IBF had remarkable increase in the growth rates of bank reserves and number of customers during the crises. ${ }^{48}$ Almost all of financial institutions have been affected by credit crisis but its negative effect on Islamic banking is almost insignificant as compared to conventional banks. ${ }^{49}$ Some of the limitations applicable to the Islamic finance industry,

46 Bambale, Y.Y., Islamic Law of Commercial and Industrial Transactions (Lagos: Malthouse Law Books, 2007), 16.

47 Farook, R., 'Global Financial Crisis Unthinkable Under Islamic Banking Principles,' www.scribd.com, http://www.scribd.com/doc/14941038/GlobalFinancial-Crisis-Unthinkable-Under-Islamic-BankingPrinciples-by-RiyaziFarook, 5th January 2017.

48 Hassan Mobeen Alam, Monazza Karamat \& Muhammad Ilyas, 'Islamic Banking: Insulation Against US Credit Crisis,' International Journal of Business and Social Science, 2/10 (2011): 9.

49 Hassan Mobeen Alam, Monazza Karamat \& Muhammad Ilyas, 'Islamic Banking: Insulation Against US Credit Crisis,' 9. 
Shariah compliance, have stopped Islamic financial institutions from investing in assets that have later turned out to be toxic, and their avoidance of heavilyleveraged companies has been of benefit to them. The restrictions applicable to Islamic finance-the requirement that investments and financings be tied to productive assets and the avoidance of speculative investments is the secret behind the success of IBF. ${ }^{50}$

Cheating through riba (usury) was rampant during the Jāhiliyyah (PreIslamic $)^{51}$ period which resulted in various passages in the Qur'ann revealed against it. Principally, IBF operates on a profit and loss sharing basis and is against the interest based form of conventional banking. The prohibition of usury is evident in a number of places within the Qur'ān and sunnah. For example, Allah says:

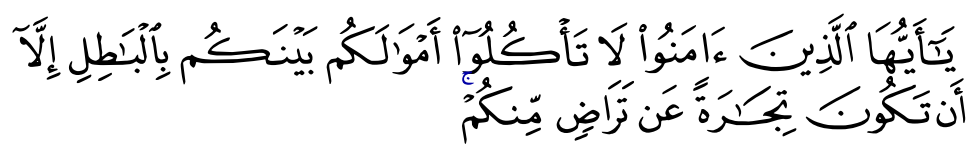

"O you who belief, Eat not up your property among your selves unjustly except it is by trade amongst you or by mutual consent..."

(Surah al-Nisā', 4: 29)

In another place, Allah stated in the Qur'ān:

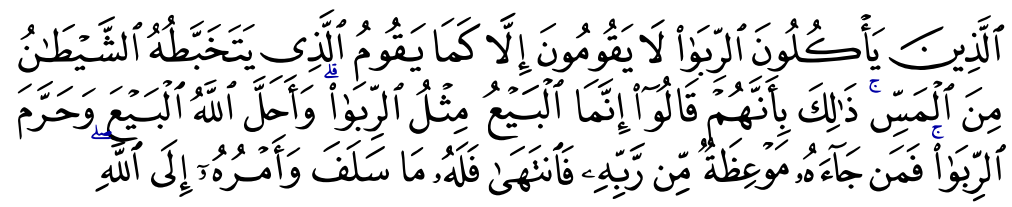

"And those who eat riba will not stand (on the day of resurrection) except like the standing of a person beaten by Satan leading him to insanity. That is because they say: Trading is only like riba (usury). Whereas Allah has permitted trading and forbidden riba (usury) who so ever receives the admonition from his Lord and stops eating riba shall not be punished for the past."

(Surah al-Baqarah, 2: 275)

Further:

50 Isam Salah, 'Islamic Finance in the Current Financial Crisis,' Berkeley Journal of Middle Eastern \& Islamic Law, 2 (2009): 137.

51 Al-Hafiz al-Asqalani \& Muhammad al-Sanani, Bulugh al-Maram (Riyad: Dar Assalam Publication, 1996), no. hadìth 648, 273-274. 


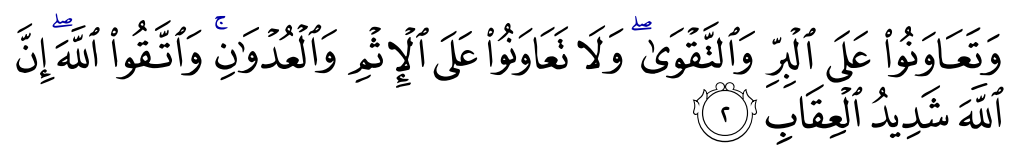

"Help you one another in al-birr and at-taqwa (virtue, righteousness, and piety); but do not help one another in sin and transgression. And fear Allah verily, Allah is severe in punishment."

(Surah al-Mā'idah, 5: 2)

\section{b) The Hadīth}

Hadith is second only to the laws governing IBF, not only in Nigeria, but for all Muslims around the world. In this respect, the Prophet (PBUH) is reported to have said that Allah has cursed the person who devours usury; its payer, its scribe and its two witnesses are all equal in sin. In a hadìth narrated by Abū Hurayrah, the Prophet (PBUH) said:

"Avoid the seven great destructive sins." They (the people) asked, "O Allah's Apostle! What are they?" He said, "To join partners in worship with Allah; to practice sorcery; to kill the life which Allah has forbidden except for a just cause (according to Islamic law); to eat up usury (riba), to eat up the property of an orphan; to give one's back to the enemy and fleeing from the battlefield at the time of fighting and to accuse chaste women who never even think of anything touching chastity and are good believers. " 52

When a man confessed to the Prophet (PBUH) that he used to cheat in his business transactions, the Prophet (PBUH) then directed that there should be no treachery or cheating in business transactions. ${ }^{53}$

\section{c) Fatawa (Authoritative Scholarly Decisions) Made by Experts Advisory Council (EAC)}

This is the equivalent of the NSAC (National Shariah Advisory Council) in Malaysia. Aside from offering professional advice to the Bank or the financial institution, it is used to determine the compliance or compatibility status

\footnotetext{
52 Al-Bukhārī, Șaḥịh al-Bukhārī (Beirūt: Dār al-'Arabiyyah, 1980), no. hadīth 840.

53 Imam M. A., Muwatta Imam Malik, Narrated by Yahya Y.K., Al-Laithi A. trans. Amira F.Z.M., rev. Mahmoud M. (Beirut: Dar El-Fitri, 2008), no. hadīth 1393.
} 
of proposed products, effectively having become a mini-legislature. ${ }^{54}$ The difference with the Nigerian Central Bank Sharia Advisory Council is the lack of a specific, special, or separate Act for the creation and operations of the council.

\section{Constitution of the Federal Republic of Nigeria 1999}

The Nigerian Constitution is the supreme law of the land. In the words of the Black's Law Dictionary, a constitution is:

"The organic and fundamental law of a nation or a state which may be written or unwritten, establishing the character and concept of its government laying the basic principles of which its internal life is to be conformed, organizing the government and regulating distributing and committing the functions of its different departments prescribing the extent and manner of sovereign powers..." 55

A significant feature of a constitution is that it is regarded as a supreme law endowed with higher status in a degree over and above other legal rules in its system of government. ${ }^{56}$

The Nigerian Constitution provides:

"This Constitution is supreme and its provision shall have binding force on all authorities and persons throughout the Federal Republic of Nigeria..." 57

The Constitution states further that if any other law is in conflict with any of its provisions, the conflicting law shall be void based on inconsistency. ${ }^{58}$ The 1999 Constitution, and all other renditions of the Nigerian Constitutions that predate it, have not mentioned IBF directly. ${ }^{59}$ However, all laws dealing with

54 Buang, A. H., Mahkamah Syariah di Malaysia: Pencapaian dan Cabaran (Kuala Lumpur: University of Malaya Press, 2005), 325; Rachagan, S., 'Islamic Banking in Malaysia,' Journal of International Banking Law and Regulation (2005): 92.

55 Garner, A.G. (ed.), Black's Law Dictionary (USA: Thomson West, 2004), 231.

56 Ibrahim, B.Y., 'An Appraisal of the Oversight Function of the Judiciary over the Legislative and the Executive Under the American and Nigerian Constitutions,' Usman Danfodio University Sokoto Journal of Islamic Comparative Law (UDUSJICL), 2 (2010): 52.

57 Section 1(1) CFRN 1999.

58 Section 1(3) CFRN 1999.

59 Nigeria has had different constitutions at different times such as the 1963 and the 1979 Constitutions [revised]. 
the system derive their validity and roots from the Constitution even where such laws are made before coming into force of its provisions. According to Section 315 of the Constitution, all laws valid before the coming into force of the Constitution are deemed valid as if they were made by the Constitution.

The Nigerian Constitution has guaranteed every citizen the right to religion and conscience, stating:

"Every person shall be entitled to freedom of thought, conscience and religion, including the freedom to change his religion or belief and freedom (either alone or in community with others and in public or in private) to manifest and propagate his religion or belief in worship, teaching, practice and observance." 60

Since Islam is a complete way of life, a Muslim has the right to practice every aspect of his religion including the right to avoid transactions that are contrary to the dictates of his religion, such as riba (usury). It therefore follows that the establishment of Islamic banking is a constitutional right of the Nigerian Muslims and any attempt to do otherwise is clearly a denial of said right.

According to Mowoe, ${ }^{61}$ respecting constitutional rights is an international obligation of Nigerians and the Nigerian government, and that the rights that pertain to Nigerians are not limited to those contained in the Constitution, but also the African Charter on Human Rights, ${ }^{62}$ and other international human rights instruments. ${ }^{63}$

However, this right shall not be exercised in such a manner as to contravene the provisions of the Constitution; thus, IBF shall not be imposed on any citizen of Nigeria. The Constitution has equally stated that no state shall practice the dictates of any religion to such an extent as to declare such religion as a state religion. ${ }^{64}$ Similarly, the Constitution has provided that no citizen of

$\overline{60}$ Section 38(1) CFRN 1999.

61 Mowoe, K., Constitutional Law in Nigeria, vol. 1 (Nigeria: Malthouse Press, 2003), preface page.

62 Article 8 provides for the freedom of conscience: "The profession and free practice of religion shall be guaranteed. No one may, subject to law and order, be submitted to measures restricting the exercise of these freedoms." See African Charter on Human and Peoples' Rights (Ratification and Enforcement) Act. Chapter A9 (Chapter 10 LFN 1990) (No. 2 of 1983) Laws of the Federation of Nigeria 1990.

63 See for instance United Nations' Declarations on Religious Intolerance 1981, Article 1 (1) which has the same provision with Section 38(1) of the Nigerian Constitution.

64 Section 10 CFRN 1999. 
Nigeria shall be discriminated on the basis of ethnic group, place of origin, sex, religion, and political opinion. ${ }^{65}$

That said, the establishment of an Islamic bank does not contravene the

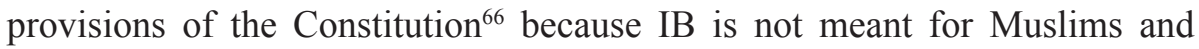
it is also in compliance with other laws that regulate the banking industry in Nigeria. Thus apart from being Shariah compliant, it must equally be in accordance with all the laws regulating other banks. ${ }^{67}$

Before the establishment of IB, Muslims in Nigeria have had problems over the years transacting with conventional banks due to their operations with interest and products which inconsistent with the Shariah. Some take the risk of not dealing with banks at all. They therefore take the risk of keeping their money at home or some other unsafe spaces while others deal with the banks through digital accounts. Accordingly, opposition to the operations of IB in Nigeria is not only a contravention of a constitutional right, but also an act of injustice that is not supposed to come from one that accommodates and respects the belief and right of others. The courts in Nigeria ${ }^{68}$ have taken the lead in making clear that every citizen has the right to practice his religion and the court will not allow any person or authority to deny any citizen this constitutional right. ${ }^{69}$

It is apparent that although the constitution has not expressly mentioned IBF, since it is secularly believed to be the "Grand Norm" (supreme secular

\footnotetext{
65 Section 42(1) CFRN 1999.

66 Unfortunately, the Christian Association of Nigeria (CAN) came out to criticize IB and maintained that it is unconstitutional. This opinion is clearly motivated by the seemingly unfriendly attitude of the Association towards Islam and Muslims. It is hoped that a day will come when Nigerians will appreciate the importance of the Bank and will be ready to accommodate one other. Chikezie revealed that the unequivocal denouncement of IBF by CAN was based on the premise that the introduction of IB is an attempt to Islamize Nigeria. Chikezie, E.P., 'Islamic Banking in Nigeria: Perceived Relative Advantage among Religious Groups in Anambra State,' An International Multidisciplinary Journal, Ethiopia, 8/2 (2014): 162.

67 Chiroma, M., 'Legal Feasibility and Economic Viability of Establishing I.B.: An Analysis under the Nigerian Legal Framework,' University of Ibadan (Unib) Law Journal, 1/1 (2011): 92.

68 See Section 6 CFRN 1999.

69 See Bashirat Saliu and 2 Other v. The Provost Kwara State College of Education Ilorin and 2 Others (Unreported) suit no. kws $/ 28 \mathrm{~m} / 2006$ ruling delivered $8^{\text {th }}$ May, 2006.
} 
law), ${ }^{70}$ all other laws derive their validity from it and as such it is appropriate to submit that the Constitution is a very vital legislation to this subject. After all, both the supporters and those who oppose the system rely on the Constitutional provisions to support their arguments.

Despite provisions under the CBN Act 2007 and BOFIA on the creation of non-interest banking in Nigeria, the aspect of litigation relating to IBF has not been fully covered by the law as it has in other countries such as Malaysia and Indonesia. ${ }^{71}$ Previous research has analyzed the numerous provisions of the Constitution requiring amendments towards the smooth and proper adjudication of IBF matters in the Nigerian Courts. These lacunae have left very serious issues unresolved and pose future legal obstacles against the smooth running of IBF in the country. This is in view of the fact that disputes and litigations cannot be avoided in all cases relating to the subject. The issue of the powers of the governor of CBN to issue IBF licenses, as challenged in the unreported case of Godwin Sunday vs. CBN Governor, was briefly discussed under the sub-heads on BOFIA and the CBN Act. ${ }^{72}$

Though the non-interest banking and finance system has already begun and is receiving patronage from both Muslims and non-Muslims in Nigeria, ${ }^{73}$ the issue of litigation and a specific legislation with respect to the system is not well addressed. ${ }^{74}$ This, therefore, makes it necessary to proffer the following suggestions:

First, the laws, especially the Constitution, have not adequately covered the issue of litigation in this respect. Since IBF relates to issues of Islamic business transactions, the Shariah courts ${ }^{75}$ are supposed to be the appropriate avenues through which jurisdiction presides over matters relating to Islamic law. The

70 Kelsen, H., Pure Theory of Law (Legality and Legitimacy) (Oxford: Oxford University Press, 2007), 9.

71 Buang, A. H., 'Islamic Contracts in a Secular Court Setting: Lessons from Malaysia,' 330; Affin Bank Berhad v. Zulkifli Abdullah [2006] 1 CLJ 438.

72 Godwin Sunday Ogboji v. Governor of Central Bank Nigeria \& Ors. Federal High Court, Abuja. Case number 710/2011 (Fhc/Abj/Cs/710/2011).

73 Abdullahi, S. I., 'Islamic Banking in West African Sub-Region: A Survey,'; The Economist Magazine, 'Nigeria’s Moment,' 11.

74 Bello, A. \& Abubakar, M., 'Challenges and Solutions to Islamic Banking System in A Pluralistic-Secular Country like Nigeria,' Mediterranean Journal of Social Sciences (MCSER), 5/6 (2014): 1.

75 Shariah Courts include the Lower Shariah Courts, the Upper Shariah Courts (established by the Shariah Courts Edicts of various Muslim majority states) and the Shariah Courts of Appeal (as established by section 260 of the Nigerian Constitution, 1999). 
CBN governor's role should be clearly spelt out in a specific way for IBF just as it has been done in the Malaysian Islamic Financial Act, 2013.

Second, there are very serious and threatening gaps which exist in the Nigerian constitution on IBF litigations. While efforts are being put to fill those gaps, Alternative Dispute Resolutions (ADR) should be encouraged so that disputes are not even allowed to get to the stage of litigation; this minimizes costs and delays in the delivery of justice.

To fill the gaps in the Nigerian Constitution 1999 concerning IBF, there is the need for some proactive amendments. The proposals are proactive as they forestall future constitutional hindrances to the smooth operation of this important tool for inter-faith harmony (i.e. IBF). This is evident from the fact that the $60 \%$ of shareholders in the Nigerian Islamic Jaiz Bank are Christians. ${ }^{76}$

After all, Section 15(1) states that the motto of the Federal Republic of Nigeria shall be Unity and Faith, Peace and Progress; therefore IBF should be legally and constitutionally fortified and buttressed as it has proved to be a tool for achieving economic and scriptural harmony. Furthermore, Section 16(1)(d) provides that Government should, without prejudice to the right of any person to participate in areas of the economy within any of its major sectors, protect the right of every citizen to engage in any economic activity outside said major sectors. This is in line with the fact that IBF is open to all irrespective of religious or other affiliations. The diagnosis of these sections and their hypothesized legal remedies are as follows (details attached as an Appendix):

(a) Section 38(1) enshrines the right to freedom of thought, conscience and religion:

"(1) every person shall be entitled to freedom of thought, conscience and religion, including freedom to change his religion or belief, and freedom (either alone or in community with others, and in public or in private) to manifest and propagate his religion or belief in worship, teaching, practice and observance."

Avoiding what your religion prohibits is a cardinal principle of 'worship' in religions. Equally, doing what is enjoined by one's religion is 'practice and observance' of one's religious right. As an example, this can be buttressed by the fact that IBF was introduced in Malaysia in 1983 based on the religious

76 Sanusi L.S., 'Islamic Finance in Nigeria: Issues and Challenges,' (A Lecture delivered at Markfield Institute of Higher Education, UK., 17 June 2011). 
freedom guaranteed by the Malaysian Constitution. It should also be noted that:

"Respect for these rights is an international obligation on Nigerians and the Nigerian government, and that the rights that pertain to Nigerians are not limited to those contained in the constitution but also the African charter on human and peoples' rights, and other international human rights instruments." 77

There should be added the phrase "business transactions" to Section 38(1) in order to clearly include IBF transactions. It should then read as follow:

“...to manifest and propagate his religion or belief in worship, teaching, practice, business transactions and observance."

(b) Section 40 provides:

"Every person shall be entitled to assemble freely and associate with other persons, and in particular he may form or belong to any political party, trade union or any other association for the protection of his interests."

The reality that the membership of the Shariah Advisory Council of the $\mathrm{CBN}$ is based on the knowledge of the Shariah has been challenged as contrary to this provision in the sense that only Muslims can be members and therefore the rights of non-Muslims to be members of any association is infringed upon. However, this argument is not valid because anybody with knowledge of the Shariah can be a member irrespective of his belief, as seen in the membership of such committees in the IBF institutions in non-Muslim nations. However, there is a gap in this provision as it is silent on qualifications for membership. Sub-section (1) needs to be added to read:

"Nothing in this section should qualify any person to be a member of any association, council, board or similar legal bodies unless the person acquires any qualification requirement stipulated for its members."

(c) Section 42 requires a similar amendment as it is also used as a tool for challenging the membership of the Shariah Advisory experts' board of the $\mathrm{CBN}$. This section provides for the right to freedom from discrimination.

(d) Section 1(1) (3) provides on the supremacy of the constitution over the Qur'ān and the Bible:

77 Mowoe, K., Constitutional Law in Nigeria, preface page. 
"If any other law is inconsistent with the provisions of this Constitution, this Constitution shall prevail, and that other law shall, to the extent of the inconsistency, be void..."

There is the need for a proviso to this provision to respect the scriptures which guide the entire activities and livelihood of Nigerians who are either Muslims or Christians. A proviso should provide thus:

"Provided that no provision of the Qur'ān or the Bible which directly affects worship is made void by this provision..."

With this exception, IBF operations cannot be hindered by any allegations of unconstitutionality in so far as it operates according to the scriptures.

(e) Section 45 provides for the restriction of and derogation from fundamental human rights including freedom of religion in emergency situations. To avoid misuse of this power by a possible religiously sentimental President, a proviso should be added to this section to empower the Judiciary to check any misuses which may hinder IBF operations.

(f) Section 6 vests judicial powers on the Courts to interpret laws. The role of the Shariah Advisory Council in the CBN was seen as tantamount to exercising judicial powers and therefore in conflict with the Constitution. However, this is not so because its role is merely advisory; advising the banks through interpretation of the Shariah regarding compliance issues. A proviso can be added to clarify this relationship.

(g) Section 4 provides for legislative powers. The question was asked, are the Shariah Advisory Councils of the CBN and other Banks mini-legislatures? However, they are not in any way assuming this constitutional power for the reason stated above in Section 6. A proviso or a sub-section can be added to clarify this issue and forestall future obstacles to the operation of the council.

(h) Section 4(8) provides that the National Assembly or House of Assembly shall not enact any law that ousts or purports to oust the jurisdiction of a court of law or of a judicial tribunal established by law (including the exclusive jurisdiction of the Federal High Court (FHC) to handle Islamic Banking (IB) matters). There is no need to oust the jurisdiction of the FHC; all that is needed is to appoint Muslim judges learned in Islamic law in the court in addition to vesting such powers on the Shariah Courts. If that is not feasible, then Section 4(8) should be clarified by adding the phrase "except through amendments." 
(i) Section 9 provides for the mode of altering provisions of the Constitution; requiring two thirds of the National Assembly in addition to two thirds of the states' Houses of Assembly. This should be relaxed to one third in matters relating to the enhancement of national harmony, like IBF. That is why this research suggests the setting up of special courts or tribunals to handle IBF matters in addition to ADR bodies with powers to enforce their decisions, such as practiced in Dubai.

(j) Section 10 prohibits the establishment of a state religion. There are arguments that the establishment of IBF amounts to Islamizing Nigeria and is therefore unconstitutional. This argument cannot be sustained because the system currently operates in non-Muslim nations and nothing in the laws establishing it have led to the establishment of a state religion. A proviso to this section is required to the effect that establishing religion based institutions does not constitute establishing a state religion.

(k) Section 231(3) provides for the qualification of the Chief Justice and Justices of the Supreme Court (SC). This section should be amended to replace the phrase "Islamic personal law" with "Islamic law" so that Justices learned in IBF will be appointed to properly handle such matters.

(1) Section 232 and 233 enshrine the original and appellate jurisdictions of the Supreme Court. This should also be amended to include matters of IBF.

(m) Section 238(3) stipulates the qualification of Justices of the Federal Court of Appeal (FCA). This is a similar suggestion regarding the aforementioned SC justices; they should be learned in Islamic law, not just personal law, which does not include IBF.

(n) Section 239 and 240: Original and appellate jurisdictions of the Federal Court of Appeal. Same suggestion as that of the SC justices; they should be learned in Islamic law, not just personal law.

(o) Section 244(1) provides for appeals from State Shariah Courts of Appeal to the Federal Court of Appeal. This should be amended to include Islamic law in general, including IBF laws.

(p) Section 244(2)(b) provides for FCA procedure in Shariah related matters. This should be amended to add Islamic law procedures and not just personal law procedures.

(q) Section 247(1) states that to determine appeals from the SCA (Shariah Court of Appeal) the FCA Panel should consist of not less than three Justices of the Court of Appeal learned in Islamic personal law. The word "personal" must be removed so that it should read "Islamic Law". 
(r) Section 251(1)(d) vests exclusive Jurisdiction with the FHC on matters relating to Banks and other financial institutions (like takaful companies); except between a bank and a human individual. This is the most controversial provision as it arrogates the jurisdiction on banking and finance matters to only the FHC. It should be amended to include a proviso:

"Provided that this section does not prevent the vesting of jurisdiction to determine Islamic Banking and Finance related Civil and Criminal cases by any other court."

(s) Section 251(1) (j) provides Exclusive FHC Jurisdiction on matters relating to bankruptcy and insolvency (even if individuals are involved). This should also have the same amendment as Section 251(1)(j).

(t) Sections 256(3) and 271(3) enshrine for the qualifications of Judges of $\mathrm{HC}$ of the Federal Capital Territory, Abuja, and state HC. Since Judges of these courts determine matters of IBF between individuals and banks, there should a Malaysian type Shariah Panel. Members of this panel must be learned in Islamic law generally. This should be achieved through amendment of this provision.

(u) Section 261(3) covers the qualification for Kadis (judges) of the SCA of Abuja: As modern IBF matters entail both the Shariah and Civil law, the "or" in this provision should be changed to "and". As controversial as it might be, a person should not qualify to be a Kadi just because he is an Islamic scholar; he should also have the qualifications of a lawyer. This will update the Shariah Courts and they would no longer be despised by the HC judges.

(v) Section 262(1) says that the jurisdiction of the SCA Abuja can be increased by the National Assembly; there should be an amendment which clearly states that the increase is not only on personal law but Islamic law generally. The same applies to the provision on the jurisdiction of the state SCA.

(w) Section 262(2): appellate Jurisdiction of SCA Abuja on civil, Islamic personal law matters (excluding IBF matters). The court should have both original and appellate jurisdiction to determine IBF matters. The same should apply to the state SCA.

(x) Sections 264 and 279: powers of Grand Kadis of Abuja and the states, respectively, to make rules for regulating the practice and procedure of their courts. This should be reviewed to reflect the original and appellate jurisdictions to try IBF matters. 
(y) Section 288(1) and (2)(a) assert that the President shall have regard to the need to ensure that there are among the holders of the offices of Justices of FCA and the SC, persons learned in Islamic personal law (note: only personal law).

By virtue of Section 4, and since the CBN Act, BOFIA and Insurance Act are products of this constitutional provision, the National assembly should put economic and religious sentiments aside and have the political will to amend the Constitution and all other relevant laws for the smooth operations of IBF in Nigeria.

\section{Banks and Other Financial Institutions Act (BOFIA), 1991}

The Supreme Military Council ${ }^{78}$ in 1991 promulgated the Banking and Other Financial Institutions Decree No. 25, $1991^{79}$ which for the first time in the history of banking in Nigeria deviates from conventional banking. It provided for a new kind of banking that is based on profit and loss sharing. The Act states that the President, on the recommendation of the Governor of the Central Bank, shall from time to time determine as he deems appropriate the minimum paid up capital of each category of banks. ${ }^{80}$

According to Sanusi, IB falls under the category of a "specialized bank" recognized by the BOFIA $1991 .^{81}$ On the main, non-interest banking and financial models are broadly divided based on Islamic commercial jurisprudence and non-interest banking and finance based on any other established law on interest principle. ${ }^{82}$

IB, as one of the models of non interest banking, serves the same purpose of providing financial services as commercial financial institutions do. The difference is that the former operates on the principles and rules of Islamic commercial jurisprudence that recognizes profit and loss sharing and the prohibition of interest, uncertainty and ambiguity relating to the subject matter, as well as terms and conditions. Other prohibitions are gambling, speculation, unjust enrichment, exploitation, and other unfair trade practices.

\footnotetext{
78 This was the highest law/decision making body in Nigeria during the Military era.

79 This Decree has automatically become or is deemed an Act of the National Assembly by virtue of Section 315 CFRN 1999. The BOFIA is now codified as Cap B3 Laws of the federation of Nigeria, 2004.

80 Section 9 of BOFIA.

81 Sanusi L.S., 'Islamic Finance in Nigeria: Issues and Challenges,' 6-7.

82 Sanusi L.S., 'Islamic Finance in Nigeria: Issues and Challenges,' 6-7.
} 
Also prohibited in the IBF system are dealings in pork, alcohol, arms and ammunition, pornography, as well as transactions, products, and goods and services which are not compliant with the rules and principles of Islamic commercial jurisprudence. ${ }^{83}$

Since IB is a peculiar kind of bank, the Bank and other Financial Institution Act (BOFIA) No. 25, of 1991 (as amended) made provisions for a number of exceptions to facilitate the smooth operations of non-interest banking. For example, the non-applicability of the need to display the interest rate in the bank premises of a profit and loss sharing bank. The Act states:

"Every bank shall display at its offices its lending and deposit interest rates and shall render information on such rates as may be specified, from time to time, by the bank, provided that the provisions of this subsection shall not apply to profit and loss sharing banks." 84

The Act further states that the Governor of the Central Bank of Nigeria can further exempt the profit and loss sharing bank from any of the provisions of the BOFIA as he thinks appropriate. ${ }^{85}$ These provisions are set to exempt the profit and loss sharing banks from some of the shackles that could hinder its smooth operation is indeed a solid foundation that will assist in the successful establishment and operation of IB. This move has however left some lacunae that could at the end affect the smooth operation and trust of the public on the bank. For example, the Act does not require the inclusion of memorandum and articles of association of the prospective Islamic bank which will spell out the establishment, composition, and qualifications of the members of board. The powers of the Governor of the Central Bank to make rules and regulations are restricted to the area of practice and procedure. ${ }^{86}$ This will, in the long run, pose a challenge to Islamic banking. The Act is equally silent on the establishment of the Shariah Advisory Board which at a glance does not look like a serious problem, but could be a problem to the bank and its operations; after all, consultation is highly valued by the Shariah as Allah enjoins:

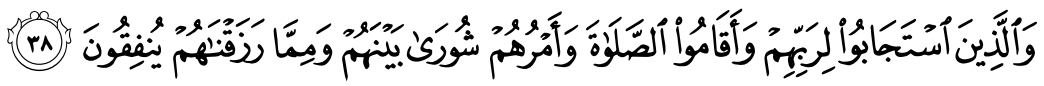

\footnotetext{
83 Sanusi L.S., 'Islamic Finance in Nigeria: Issues and Challenges,' 6-7.

84 Section 23(1) BOFIA 1991.

85 Section 52 BOFIA 1991.

86 Section 57 BOFIA 1991.
} 


\begin{abstract}
"Those who answered the call of their Lord, and establish regular prayer (salāh) and whose affair are a matter of counsel and spend out of what we bestow on them for sustenance.."
\end{abstract}

(Surah al-Shūrā, 42: 38)

In Malaysia, the IB Act is a good example of how Islamic banking is supposed to perform with requirements of Memorandum and Article of Association and a Shariah council as part of the conditions before a bank receives license to operate as an Islamic Bank. Section 3(5)(b) of the IB Act of Malaysia provides that the Central Bank shall not recommend the grant of a license, and the Minister shall not grant a license unless the Central Bank or the Minister, as the case may be, is satisfied that there is in the Article of Association of the bank concerned, provisions for the establishment of a Shariah Advisory Body, as may be approved by the Central Bank to advise the bank on the operations of its banking business in order to ensure that they do not involve any element which is not approved by the religion of Islam. ${ }^{87}$

In Nigeria, unlike in Malaysia where there is a special law enacted to regulate IB, the BOFIA is the key law which includes granting license to IB. A careful perusal of the law reveals that no mention was made in the law of the term "IB". In fact, the Act required the written consent of the Governor of the Central Bank for the use of the following terms by prospective banks when applying for registration or incorporation:

“...Central, Federal, Federation, National, Nigeria, Reserve, State, Christian, Islamic, Muslim, Quranic or Biblical..." 88

The Central Bank relying on this provision issued a circular which proposes to prohibit the use of the phrase "IB". ${ }^{89}$ The circular could be ultravires to the BOFIA which has not prohibited the use of the phrase "Islamic Banking"; rather, it restricts and subjects its usage to prior consent and approval by the Governor of the Central Bank. ${ }^{90}$ Each such application is expected to be treated on its merit. Approval should be granted if the application is shown to be the aspiration of the majority shareholders and the bank is also satisfied that all the prerequisites of a licensed bank have been met. ${ }^{91}$

87 Financial Services Act (FSA) 2013 (formerly Islamic Banking Act 1983 and Takaful Act) of Malaysia; Act 276 Laws of Malaysia.

88 Section 39(1) (a), BOFIA 1999.

89 Paragraph 10(1) CBN Draft Framework 2009.

90 Abikan, I.A., The Legal Framework for Islamic Banking in Nigeria,' Usman Danfodio University Sokoto Journal of Islamic Comparative Law (UDUJICL), 2 (2010): 22.

91 Abikan, I.A., The Legal Framework for Islamic Banking in Nigeria,' 22. 
Whether or not the word ' $\mathrm{IB}$ ' is used, to a Muslim, the ends justify the means. Under Islamic law, actions are judged according to intentions. ${ }^{92}$ Since the bank operates on the Islamic principles of profit and loss sharing and the avoidance of unlawful or forbidden qualities, like wine, pigs, corpse, human blood and riba, the non-use of the word 'Islamic' does not provide a significant obstacle to the objectives of the system. ${ }^{93}$

It is worth mentioning that before a profit and loss sharing bank could engage in sales or the disposal of real estate transactions, a written approval of the Central Bank Governor would need to be obtained. ${ }^{94}$ It is not clear from the Act whether or not such approval is required for every transaction. ${ }^{95}$ Suffice it to say, such a restriction is capable of hampering the smooth operation of IB products, such as direct investments, BBA, ijārah wa itqān (hire and purchase), and murābahah (cost plus financing). ${ }^{96}$

\section{Central Bank of Nigeria Act 2007}

The Central Bank of Nigeria Act 2007 establishes the Central Bank. ${ }^{97}$ It is the apex bank that issues licenses and controls, and supervises the operations of all banking in Nigeria. ${ }^{98}$ Therefore, it follows that IB is under the control and guidance of the Central Bank just as all other banks in Nigeria. The Central Bank has taken steps to defend its stance by saying that it it is obliged by law to issue licenses to appropriate entities for the establishment of non-interest banking provided they meet the regulatory requirements for the said license.

As such, the Central Bank issued a Draft Framework to be a guide in the establishment of an Islamic Bank. It provides:

(a) Islamic banks, referred to as non-interest banks, shall be licensed in accordance with the requirements for a new banking license issued by the Central Bank of Nigeria from time to time. Conventional Banks operating in Nigeria may offer Shariahcompliant products and services through their non-interest banking branches or windows. However, such branches or

\footnotetext{
92 Bukhari hadìth 2529 and Muslim hadìth 1907.

93 Bambale, Y.Y., Islamic Law of Commercial and Industrial Transactions, 11.

94 Section 20(2)(c)(f)(g) BOFIA 1991.

95 Abikan, I.A., The Legal Framework for Islamic Banking in Nigeria,' 21.

96 Abikan, I.A., The Legal Framework for Islamic Banking in Nigeria,' 21.

97 Section 1 of the Central Bank Act 2007.

98 Section 2 of the Central Bank Act 2007.
} 
windows cannot offer conventional banking or interest based products and services.

(b) Banks offering non-interest banking products and services shall not include the words "Islamic" as part of their registered or licensed name. This, the draft described as being in line with the provisions of Section 39(1) of the BOFIA. They shall, however, be recognized by a uniform logo to be designed and approved by the CBN. The CBN shall require all the bank's signatures and promotional materials to carry the logo so as to facilitate recognition by consumers.

(c) The Central Bank shall set up an advisory committee on noninterest banking within the $C B N$ to be called the "CBN Shariah Council" (CSC), which will be outsourced. The Council shall advise the CBN on Islamic laws and principles for the purposes of regulating non-interest banking business.

(d) All non-interest banks are required to maintain a minimum Risk Weighted Asset Ratio of $10 \%$ or as may be determined by the $C B N$, from time to time, for the purpose of calculating its Capital Adequacy Ratio (CAR).

(e) All applications must be submitted with the required documents including a Non-refundable application fee of N500, 000.00 and a deposit of minimum capital of N25 billion with the Central Bank of Nigeria.

(f) Not later than six (6) months after the grant of an A.I.P (Approval In Principle), the promoters of a proposed bank must submit an application for the grant of a final banking license to the Director of Banking Supervision with a non-refundable licensing fee of $N 5$ million in bank draft payable to the CBN and other required documents. ${ }^{99}$

The controlling powers of the Central Bank of Nigeria over IB are seen from various angles. According to the Central Bank Act, the Central Bank can issue guidelines, rules, and regulations for the operation of banks or any institution engaging in financial services as well as for enforcing rules and regulations. The Central Bank equally gives approval and disapproval annually of the appointment of the Auditor by all banks, appoints Directors of banking, supervision, and removes ailing bank managers, staff, and directors. This is

$99 \quad$ Section 2 of the Central Bank Act 2007. 
in addition to the CBN's power to issue an order for special examinations or investigations of any bank. However, such an exercise of power is made in the interests of the public or upon an application of a director, shareholder, depositor, or creditor of the bank. ${ }^{100}$

\section{Nigerian Deposit Insurance Corporation Act 2006}

Section 1 of the Nigerian Deposit Insurance Corporation Act 2006 establishes the Nigerian Deposit Insurance Corporation (NDIC) as a government owned Insurance Corporation. The NDIC is established to protect the banking industry and provide financial guarantees to depositors. Towards the promotion and sustenance of public confidence in the banking system, the corporation is empowered to come to the aid of an insured bank in case of imminent or actual financial difficulties which may threaten payments. ${ }^{101}$ This may be in the form of liquidity support to the banks on agreeable terms giving guarantees for the bank's loan or even taking over the management of a faltering bank until its financial condition improves. In the event that the corporation exhausts all its protective alternatives and a failing bank still has to postpone payments, the corporation is obliged to pay every insured depositor up to the insurable limit. ${ }^{102}$

It is important to mention that some of the relationships between IBF and the NDIC have the element of riba and are hence contrary to Islamic law. For example, investment of the scheme's funds into the federal government's security has elements of riba. ${ }^{103}$ Also, insurance businesses generally are in conflict with the principles of the Shariah for it has elements of gambling (qimar), uncertainty (gharar), and unspecified and unknown elements (jahala). It is therefore important for the NDIC Act to be amended so that its dealings with IBF will be in consonance with the Shariah. This is a precedent towards the attainment of harmony in Nigeria as the Muslim majority will be able to perform economically within the realm of their religion as their constitutional rights.

\footnotetext{
100 Section 51 of the Central Bank Act 2003 and sections 31, 32, 33, 35 and 40 of BOFIA.

101 Section 2(1) (b) \& 37(2) of the NDIC Act 2006.

102 Section 20(1) of the NDIC Act 2006.

103 Section 13(1) of the NDIC Act 2006.
} 


\section{Case Law}

Since the courts are the ones constitutionally vested with the power of interpreting the laws, ${ }^{104}$ their role as a major source of Nigerian laws regarding IBF, is indisputable. All the state High courts and the Federal Capital Territory High Courts have jurisdiction over issues relating to banking, generally including IB. However, where the matter relates to dispute between banks, only the Federal High Court has the exclusive jurisdiction. Appeals from the decisions of these courts rests in the Court of Appeal and then the Supreme Court. Therefore, the decisions of these courts are a source of law for IBF as they are binding on all lower courts.

As IBF in Nigeria is at its nascent stage - unlike Malaysia, Indonesia, India, Pakistan and the U.A.E - the most popular unreported case is the one in which the legality of the only fully fledged IB in the country was challenged. On $15^{\text {th }}$ June, 2012, Justice Gabriel Kolawale of Abuja Federal High Court declared, by obiter dictum, the Jaiz Bank's license as ultravires was null and void, although fortunately he did not withdraw or revoke the license. He declared that:

"Firstly, there are no provisions in the CBN Act and the Banks and other financial Institutions Act (BOFIA) that empowers the CBN Governor Sanusi Lamido Sanusi to issue license for noninterest financial institution to operate under the principles of Islamic jurisprudence without the approval of the head of state through the minister of finance.... Secondly, unlike the other specialized banks, the Jaiz International Bank PLC, can only be established in the country with the intervention of the National Assembly by amending the BOFIA Act.... Thirdly, if not because the plaintiff had no locus Standi (The right or capacity to bring an action) to maintain this action, I would have nullified the illegal license issued to the Jaiz International Bank PLC by the CBN to operate non-interest banking under the principles of Islamic jurisprudence.... Fourthly, that this case is hereby struck out for lack of locus Standi, but the AGF should take steps to remedy the situation, and further ensure that the CBN carries out its duties within the provisions of the law establishing it..." 105

Although the court was silent about the applicant's plea to declare the licensing of the bank as tantamount to declaring Islam as a state religion and

\footnotetext{
104 Section 6 CFRN 1999.

105 Godwin Sunday Ogboji v. Governor of Central Bank Nigeria \& Ors (2011) Supra.
} 
economic discrimination based on religion - contrary to Sections 10 and 16(1) (d) of the Constitution - this legal ground poses a potential threat to IBF; hence the discussion in this research to forestall its negative consequences in case the Federal Attorney General, who has the locus standi, decides to file such a case.

This Nigerian legal problem pertaining to IBF can be remedied by learning from Malaysian case law. There are two leading Malaysian cases relevant in this context: firstly, in the case of Bank Islam Malaysia Berhad (BIMB) $v$. Adnan bin Omar, ${ }^{106}$ there was a preliminary objection raised by the Defendant claiming that the Malaysian Civil Courts, unlike the Shariah Courts, have no jurisdiction over IB litigations. ${ }^{107}$ The court overruled the objection on the ground that since banking matters are under the Federal Legislative list, it has jurisdiction to entertain the case. ${ }^{108}$

There was an amendment to the Central Bank of Malaysia Act 1958 (now 2009) (CBMA) which has incorporated the following:

"Where in any proceedings relating to Islamic banking business...or any business which is based on Shariah principles and is supervised by the Bank (Central Bank of Malaysia) before any court or arbitrator any question arises concerning a Shariah matter, the court or the arbitrator, as the case may be, may take into consideration any written directives issued by the Bank pursuant to subsection (7); or b) refer such question to the Shariah Advisory Council for its ruling. " 109

Whenever necessary, the civil court judge, trained in secular and Common law, will interpret the Shariah law and apply it before he/she comes to a decision. ${ }^{110}$ This is the main problem focused on in this research as the situation is the same under the 1999 Nigerian Constitution. Detailed suggestions for constitutional amendments are contained in the Appendix.

106 Bank Islam Malaysia Berhad (BIMB) v. Adnan bin Omar (1994) 3 CLJ 735.

107 There was an amendment to Article 121 of the Malaysian Federal Constitution 1957, in 1988, which restrains Civil Courts from having jurisdiction to hear cases where Islamic law is applicable and is now vested in the Shariah Courts.

108 Yasin, N. M., Legal Aspects of Islamic Banking: Malaysian Experience, Islamic Banking and Finance: Fundamentals and Contemporary Issues (Jeddah: Islamic Development Bank (IDB), 2006); Azma, N., I 'Issues and Prospects of Islamic Hire Purchase Financing: Malaysian Evidence,' Journal of Management Research, 6/1 (2014): 14.

109 Central Bank of Malaysia Act (CBMA) 1958 (now 2009).

110 Central Bank of Malaysia Act (CBMA) 2009. 


\section{CONCLUSION AND RECOMMENDATIONS}

The banking laws in Nigeria have come a long way, but the principle of IBF, otherwise called "profit and loss sharing banking and finance", came about as a result of complaints by Muslims that it is their Constitutional right to practice their finances in accordance with their religious regulations. Not seeing IBF as the constitutional right of Nigerian Muslims could be an indication of lacking respect and accommodation for their Islamic beliefs. ${ }^{111}$

The BOFIA is the first legislation that laid the foundation for IBF in Nigeria; other legislations, like the CBN Act and the NDIC Act, equally made provisions touching on the establishment and operation of IBF. However, some provisions in these legislations are either directly in conflict with the Shariah or could create difficulty or pose challenges to the smooth operation of the system. It is therefore appropriate to amend these legislations so that the goals of Nigerian Muslims to have a fully Shariah compliant banking and financial system might come to fruition. As the Christians in Nigeria are fully enjoying their laws, as per Lord Summer's Judgment/Dictum in Bowman v. Secular Society (1917), ${ }^{112}$ the Muslim majority should be allowed to adhere to Allah's saying:

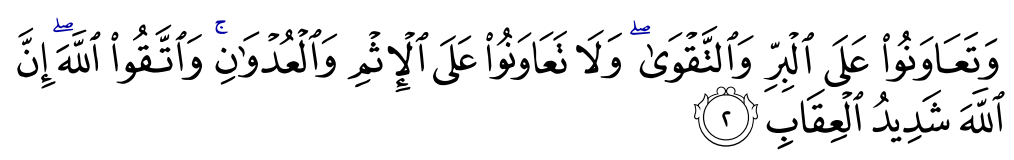

"Help you one another in al-birr and al-taqwa (virtue, righteousness and piety); but do not help one another in sin and transgression. And fear Allah verily, Allah is severe in punishment."

(Surah al-Mā'idah, 5: 2)

Considering the above facts about Nigerian Muslims, IBF can be safely said to be their fundamental right and hence this work seeks to rectify any conflicts in the laws relating to the subject. Hence, why the spot light is on the Constitution itself.

111 Abdul-Razzaq Alaro, 'Non-Interest Banking and the Enabling Nigerian Laws: The Need for an Unprejudiced Assessment,' Journal of International Banking Law and Regulation (JIBLR) (2013): 145.

112 Bowman v. Secular Society (1917) Appeal Cases (AC) 406. 
From the foregoing conclusions, the following propositions have been made with the optimism that it will facilitate the reinvigoration and strengthening of the existing legal framework in the operations of, and litigations on, IBF in Nigeria as well as for future research on the subject:

(i) This could be achieved through the method of identifying the legally based complaints against IBF and proffering legal solutions by resorting to provisional statutory amendments since said amendments will take time; through mass mobilization and Scriptural legal provisions, as they provide a coherence platform for the removal of religious bias in this subject. This is sine quo non to the desired success of IBF in Nigeria.

(ii) There is the need for a specialized legal and regulatory framework for IBF in Nigeria. As parities exists between the Islamic and the conventional Banking and Finance systems, it is natural, fair, and logical that there should be a lex specialis (specialized law) to lay down a sound foundation for the operation of IBF to complement existing legal and regulatory infrastructure. ${ }^{113}$ In other words, IBF should be liberated from the marriage of legal framework with conventional Bank regulations and should be permitted to transact outside that. For example:

(1) The prohibition making capital participation (in the form of owning shares) in certain businesses should be lifted against IBF. The prohibition was due to the profit and loss sharing principles in IBF.

(2) Nigerian laws need to incorporate the profit and loss sharing principles which form the backbone of IBF. Example, the mudārabah transaction should be made within the ambit of the Nigerian legal system as it entails the transfer of ownership resembling the common law trust. Unlike mudārabah, Nigerian laws do not recognize dual ownership in equity and in law. This is notwithstanding the fact that the profit sharing aspects of a mudarabah transaction can be accommodated by the 'freedom of contract' principle where parties are at liberty to fix their profit shares.

(3) Establishment of laws related to leasing and asset securitisation should be made part of the suggested single IBF Act of Nigeria.

(4) Trust arrangement legal ownership can be separated from beneficial ownership. The principles of equity are essential to the success of IBF and should be imbibed in the proposed Act.

113 Reza Djojosugito, 'Legal Aspects of Islamic Banking: Indonesian Experience,' Islamic Research and Training Institute Islamic Banking and Finance: Fundermentals and Contemporary Issues (Jeddah: Islamic Development Bank (IDB), 2006). 


\section{A NOTE FOR FURTHER RESEARCH}

1) Drafting of the proposed IBF Act of Nigeria.

2) Drafting amendments to the existing legal framework as a prelude to drafting the main IBF Act and to streamline IBF window activities in conventional Banks.

3) Drawing a curriculum for the training of Bank executives, Judges, Kadis, Lawyers and other stake holders in IBF operations and litigations.

\section{REFERENCES}

Abdullah, U. Y., Sharia in Africa (Ijebu-Ode: Shebiotimo Publication, 1998).

Abdullahi, S. I., 'Islamic Banking in West African Sub-Region: A Survey,' Arabian Journal of Business and Management Review (OMAN Chapter), 2/7 (2013).

AbdulQadir Abikan, 'Constitutionality of Islamic Banking in Nigeria,' in Contemporary Jurisprudence in Islamic Jurisprudence (Benin: Rawel Fortune Resources, 2009).

AbdulQadir Abikan, 'The Legal Framework for Islamic Banking in Nigeria,' Usman Danfodio University Journal of International Comparative Law, 2 (2010).

Abdul-Razzaq Alaro, 'Non-Interest Banking and the Enabling Nigerian Laws: The Need for an Unprejudiced Assessment,' Journal of International Banking Law and Regulation (JIBLR) (2013).

Abdurrahman Doi, Sharia: The Islamic Law (Kano: al-Yassar Publishers, 2007).

Abu Muhammad Ibn Abu Zaid, Risala (Kano, Nigeria: Aliyu Dala Publishers, n.d.).

Abu Muhammad Ibn Abu Zaid, Risala, 3h2, Basic Maliki Fiqh, Qayrawani kayrawani, Amira Zrein Matraji HB 279PP (Lebanon: Dar al-Fikr, 1994).

Abubakar Orisankoko, 'Socio-Economic and Legal Challenges of Shari'aCompliant Banking Operation, Its Developmental Impacts and the Struggles of the Believers: Epistemological Lessons from Nigeria,' Journal of Islamic Economics, Banking and Finance, 8/2 (Apr-Jun 2012). 
Africanoutlookonline, 'Nigeria and Islam Finance,' http:/www. africanoutlookonline.com/index.php?option=com_content\&view $=$ art icle\&id=3817:nigeriaislam-finance-islamic-banking-finally-starts-innigeria, accessed $5^{\text {th }}$ January 2017.

Akíṇlàdé, K., Shehu Usman dan Fodio (Ibadan: Onibonoje Publishers, 1979).

Akintunde Obilade, The Nigerian Legal System (Ibadan: Spectrum Law Publishing, 1979).

Alao Oladimeji \& Alao Monisola, 'Islamic Banking: The Controversy Over Non-Interest,' Arabian Journal of Business and Management Review (Nigerian Chapter) 1/1 (2012).

Al-Bukhari, Șaḥ̄h al-Bukhārī (Beirūt: Dār al-'Arabiyyah, 1980).

Al-Hafiz al-Asqalani \& Muhammad al-Sanani, Bulugh al-Maram (Riyad: Dar Assalam Publication, 1996).

Alkali, Muhammad Bashir \& Ahmad Hidayat Buang, 'Challenges in Implementing Islamic Banking and Finance in Nigeria: A Legal Insight,' Shariah Journal, 23/1 (2015): 141-166.

Azma, N., I 'Issues and Prospects of Islamic Hire Purchase Financing: Malaysian Evidence,' Journal of Management Research, 6/1 (2014): 14.

Balogun, A. B., The Life and Works of Uthman dan Fodio The Muslim Reformer of West Africa (Lagos, Nigeria: Islamic Publications Bureau, 1975).

Bambale, Y.Y., Islamic Law of Commercial and Industrial Transactions (Lagos: Malthouse Law Books, 2007).

Bello, A. \& Abubakar, M., 'Challenges and Solutions to Islamic Banking System in A Pluralistic-Secular Country like Nigeria,' Mediterranean Journal of Social Sciences (MCSER), 5/6 (2014).

Buang, A. H., 'Analisis Fatwa-fatwa Semasa Syariah di Malaysia (Analysis of Current Fatwas in Malaysia),' Jurnal Syariah, 10/1 (2002): 39-53.

Buang, A. H., Fatwa di Malaysia (Fatwa in Malaysia) (Kuala Lumpur: Jabatan Syariah dan Undang-undang, Akademi Pengajian Islam, Universiti Malaya, 2004).

Buang, A. H., 'Islamic Contracts in a Secular Court Setting: Lessons from Malaysia,' Arab Law Quarterly, 21 (2007): 317-340.

Buang, A. H., Mahkamah Syariah di Malaysia: Pencapaian dan Cabaran (Shariah Courts in Malaysia: Achievements and Challenges) (Kuala Lumpur: University of Malaya Press, 2005).

Chibuike Uche, 'The Economic History Review,' New Series, 52/4 (1999): 669-691. 
Chikezie, E.P., 'Islamic Banking in Nigeria: Perceived Relative Advantage among Religious Groups in Anambra State,' An International Multidisciplinary Journal, Ethiopia, 8/2 (2014).

Chiroma, M., 'Legal Feasibility and Economic Viability of Establishing I.B.: An Analysis under the Nigerian Legal Framework,' University of Ibadan (Unib) Law Journal, 1/1 (2011).

Collins R. O., 'Kanem: Decline and Merger with Borno (c. 1400),' Encyclopedia of African History, ed. Kevin Shillington (New York: Fitzroy Dearborn, 2005).

Dauda, M., 'Legal Framework for Islamic Banking and Finance in Nigeria,' Journal of Islamic and Middle Eastern Law (EJIMEL), 1/7 (2013).

Doi, A.I., Sharia: The Islamic Law (Kano: Al-Yassar Publishers, 2007).

Economic Confidential Magazine, 'Bishop Urges Christians to Embrace Islamic Banking,' http://econo micconfidential.net/new/financial/ monetary/1027-bishop-urges-christians-to-embrace-islamic-banking, accessed $5^{\text {th }}$ January 2017.

Elombah Perspective of World Affairs, 'Regulation of Non-Interest Financial Regulation in Nigeria,' http://elombah.com/index.php/articles/70letters/7115-the-central-bank-of-igeriaislamic-banking-the-lawand-appropriate-regulation-of-non-interest-financial-institutions-in nigeria-v15-7115, accessed $5^{\text {th }}$ January 2017.

El-Yakub, K., 'An Auto-Ethnographical Study of Integration of Kanuri Traditional Health Practices into the Borno State Health Care System,' (Ph.D Thesis, Durham University, 2009).

Encyclopedia of Islam 6, 630, http://en.wikipedia.org/wiki/Jesus_in_ Islam, accessed 16 September 2013.

Fafunwa, A.B., History of Education in Nigeria (UK: George Allen and Unwin Ltd., 1979).

Falola T. \& Heaton M., A History of Nigeria (Cambridge: Cambridge University Press, 2008).

Farook, R., 'Global Financial Crisis Unthinkable Under Islamic Banking Principles,' www.scribd.com, http://www.scribd.com/ doc/14941038/Global-Financial-Crisis-Unthinkable-Under-IslamicBankingPrinciples-by-Riyazi-Farook, accessed $5^{\text {th }}$ January 2017.

First Bank of Nigeria website www.firstbanknigeria.com/about-us/ourhistory/, accessed 18 November 2012. 
Forrest Smith, 'The Regulation of Interest: Practice and Procedure,' in Maisel, The Evil of Usury, article from New Dawn Magazine, http://www. biblebelievers.org.au/usury.htm\#The\%20evil\%20of\%20usury, accessed $5^{\text {th }}$ January 2017.

Gafai Abdullah, 'Comparative Analysis of the Rights of Women in Sharia and Common Law in Contemporary Nigeria,' Journal of Islamic Science and Contemporary Development, 2 (2010).

Garner, A.G. (ed.), Black's Law Dictionary (USA: Thomson West, 2004).

George Braden, The Constitution of The State of Texas: An Annotated and Comparative Analysis (Texas: Texas State Law Library, 1977).

Hasani, I., 'Theory and Practice of Islamic Banking in Malaysia and its Implementation in Kosovo,' (PhD Thesis, Department of Shariah and Economy, Academy of Islamic Studies, University of Malaya, 2009).

Hassan Mobeen Alam, Monazza Karamat \& Muhammad Ilyas, 'Islamic Banking: Insulation Against US Credit Crisis,' International Journal of Business and Social Science, 2/10 (2011).

Helena Christofi, 'Islamic Banking in Britain,' The Brussels Journal, http:// www.brussels journal.com /node/1898, 2 December 2009, accessed 17 September 2013.

Helena Christofi, 'Islamic Banking in Britain,' The Brussels Journal, http:// www.brussels journal.com /node/1898, 2 December 2009, accessed 17 September 2013

Ibrahim, B.Y., 'An Appraisal of the Oversight Function of the Judiciary Over the Legislative and the Executive Under the American and Nigerian Constitutions,' Usman Danfodio University Sokoto Journal of Islamic Comparative Law (UDUSJICL), 2 (2010).

Imam I., et al., 'The Unending Crises on the Status of Sharia in Nigeria: A Critical Analysis,' Usman Danfodio University Sokoto Journal of Islamic Comparative Law (UDUSJICL), 2 (2010).

Imam I., et al., 'The Unending Crises on the Status of Sharia in Nigeria: A Critical Analysis,' Usman Danfodio University Sokoto Journal of Islamic Comparative Law (UDUSJICL), vol. 2 (2010).

Imam M. A., Muwatta Imam Malik hadīth, narrated Yahya Y.K., Al-Laithi A., trans. Amira F.Z.M., rev. Mahmoud M. (Beirut: Dar El-Fitri, 2008).

Isam Salah, 'Islamic Finance in the Current Financial Crisis,' Berkeley Journal of Middle Eastern \& Islamic Law, 2 (2009). 
'Islam: A Complete Way of Life,' www.muhammadanism.org/Islam/Islam Way_Life.htm, accessed $5^{\text {th }}$ January 2017.

'Islamic Finance and SRI: Any Cross Over?,' Working paper May 2009 at part 3 p. 12 www.novethic.comand http://www.responsible-investor.com/ images/uploads/resources/research/11248094270Working_paper_on_ islamic_finance_and_SRI.pdf, accessed 5 ${ }^{\text {th }}$ January 2017.

Jamal Elbaff, 'Provocations of Islamic Banking Antagonists,' http://dailytrust. dailytrust.com/index.php?option $=$ com_content\&view $=$ article $\&$ id $=2171$ 6:provocations-of-islamic-bankingantagonists\&catid=7:opinion \&Itemi $\mathrm{d}=12$, accessed $5^{\text {th }}$ January 2017.

Jno Kimmons, 'Usury: What is It, and Does the Law of God Forbid It, Maisel, The Evil of Usury,' New Dawn Magazine, http:// www.biblebelievers. org.au/usury.htm\#The\%20Evil\%20of\%20Usury, accessed $5^{\text {th }}$ January 2017.

Ken Warner, 'Give Us a King,' Maisel, The Evil of Usury, article from New Dawn Magazine, http://www.biblebelievers.org.au/usury.htm\#The\%20 Evil\%20of\%20Usury, accessed $5^{\text {th }}$ January 2017.

Michael Eboh, 'Nigeria: CBN Grants Islamic Banking Licence to Stanbic IBTC,' Vanguard News Paper, http://allafrica.com/stories/201107050290.html, $5^{\text {th }}$ July 2011.

James Burns \& Robert Collins, A History of Sub-Saharan Africa (Cambridge: Cambridge University Press, 2007).

Jorgen Nielsen \& Lisbet Christoffersen, Shari 'a as Discourse: Legal Traditions and the Encounter with Europe (Farnham, UK: Ashgate, 2010).

Kelsen, H., Pure Theory of Law (Legality and Legitimacy) (Oxford: Oxford University Press, 2007).

Kpr37, 'The Nigerian Jihad in Historical Perspective (The Sokoto Caliphate and Boko Haram),' www.newsvine.com, accessed 12 March 2014.

Last M., The Sokoto Caliphate (London: Longmans, Green and Co, 1967).

Lawrence Dennis, 'The Squirrel Cage of Debt,' Saturday Review of Literature 661, 24 June 1933.

Madupe A.N. et al., 'The Economic Right of Women Under Islamic Law: The Obstacles and Challenges in Contemporary Nigeria,' Human Rights Review, 3 (2012).

Manni Crone, 'Shari'a and Secularism in France,' Islam and Christian-Muslim Relations, 22/4 (2011). 
Meek, C. K., The Northern Tribes of Nigeria, vol. 2 (London: Frank Cass, 1971).

Mohammad Ahmad \& Izzatullah, 'Islamic Banking Laws: Feasibility of Implementation in Nigeria,' International Comparative Law Report (ICLR) vol. 14 (1994).

Mohammed Sule, 'Islamic Concept of the International Law (The Siyar),' Ahmadu Bello University Law Journal (ABULJ), vol. 27-28 (2008).

Mowoe, K., Constitutional Law in Nigeria, vol. 1 (Nigeria: Malthouse Press, 2003).

Muhammad Abdul-Fattah, 500 Questions and Answers on Islamic Jurisprudence, ed. Reima Shakeir (Lahore: Dar al-Manar, 2006).

Muhammad Hashim Kamali, 'Law and Society: The Interplay of Revelation and Reason in the Sharia,' Oxford History of Islam (Oxford: Oxford University Press, 2000).

Muhammad, L. A. \& Atte O. A., 'An Analysis of Agricultural Production in Nigeria,' African Journal of General Agriculture African Studies on Population and Health, 2/1 (2006).

Naighton, S., \& Shammugan, B., 'Interest Free Banking: A Case Study of Malaysia,' Journal of IBF, 7/3 (1990).

Naniya, T. M., 'Arab Settlers in Sub-Saharan Africa: A Survey of their Influence on Some Central Sudanese States,' A Journal of Savanna \& Sudanic Research, 1/1 (2000).

New American Standard Bible Exodus.

'Nigeria and Islamic Finance,' http://www.africanoutlookonline.com/index. php?option $=$ com_content $\&$ view $=$ article $\& i d=3817$ :nigeriaislamfinance-islamic-banking-finally-starts-in-nigeria, accessed $5^{\text {th }}$ January 2017.

Norhashimah Mohd.Yasin, 'Legal Aspects of Islamic Banking: Malaysian Experience,' Islamic Banking and Finance: Fundamentals and Contemporary Issues (Jeddah: Islamic Development Bank (IDB), 2006).

Okolo C. B., Squander Mania Mentality: Reflections on Nigerian Culture (Nsukka: University Trust Publishers, 1994).

Pat, D. \& James, O., 'Effects of the Consolidation of the Banking Industry on the Nigerian Capital Market,' Journal of Economics, 2/1 (2011):57-65

Patrick Brozzo, 'Legal Framework for Islamic Banking and Finance in Nigeria,' Electronic Journal of Islamic and Middle Eastern Law, 18, (2014). 
Paul Belien, 'First Sharia Bank in Switzerland,' The Brussels Journal, http:// www.brusselsjournal.com/node/1479, accessed 17 September 2013.

Rachagan, S. (2005). Islamic Banking in Malaysia. Journal of International Banking Law and Regulation, 92;

Reza Djojosugito, 'Legal Aspects of Islamic Banking: Indonesian Experience,' Islamic Research and Training Institute Islamic Banking and Finance: Fundermentals and Contemporary Issues (Jeddah: Islamic Development Bank (IDB), 2006).

Robert Collins, 'Kanem: Decline and Merge with Borno,' (c. 1400) in Encyclopedia of African History, ed. Kevin Shillington (New York: Fitzroy Dearborn, 2005).

Sampson I. T., 'Religion and the Nigerian State: Situating the de facto and de jure Frontiers of State-Religion Relations and its Implications for National Security,' Oxford Journal of Law and Religion, 3/2 (2014): 311339.

Sanusi L.S., 'Islamic Finance in Nigeria: Issues and Challenges,' (A Lecture delivered at Markfield Institute of Higher Education, UK., 17 June 2011).

Sherz Naighton \& Bala Shammugan, 'Interest Free Banking: A Case Study of Malaysia,' Journal of IBF, 7/3 (1990).

The Economist Magazine, 'Nigeria’s Moment,' The Economist Magazine, $20^{\text {th }}$ June 2015.

Tiberge, 'Vatican Paper Supports Islamic Finance: France wants Its Share of Sharia Banking,' The Brussels Journal (2009).

Tobi, N., Sources of Nigerian Law (Lagos: M.J. Professional Publishers Ltd., 1996).

Traditions and the Encounter with Europe (Farnham, UK: Ashgate, 2010).

Turaki A. H., 'Reps okay Islamic banking, 60\% of Jaiz shareholders are Igbo,' Transparency Nigeria.Com, 22 July 2011, http://www.transparencyng. com/index.php/news-categories/117-politics/4920-reps-okay-islamicbanking-60-of-jaiz-shareholders-are-igbo-sanusi, accessed $5^{\text {th }}$ January 2017.

UNESCO/Nigeria Instructional/Teaching Materials, 'Development of Commercial Banking in Nigeria,' http://unesconigeriatve.org/ teaching\%20materials/acc/accountancy/semester1/BFN\%20111\%20 Elements\%20of\%20banking\%201/week6.html, accessed $5^{\text {th }}$ January 2017. 
Wikipedia, 'Jaiz Bank Plc., Nigeria,'Wikipedia, http://en.wikipedia.org/wiki/ Jaiz_Bank, accessed $5^{\text {th }}$ January 2017.

Wouter Bos, 'The Netherlands Want to Become Centre of Sharia Banking,' The Brussels Journal, 17 July 2007, http:/www.brusselsjournal.com/ node/2256, accessed 17 September 2013.

Yasin, N. M., Legal Aspects of Islamic Banking: Malaysian Experience, Islamic Banking and Finance: Fundamentals and Contemporary Issues (Jeddah: Islamic Development Bank, 2006).

\section{Statutes}

Act 276 Law of Malaysia 1983.

Banks and Other Financial Institutions Act (BOFIA), 1991 (as Amended).

C.B.N, Draft Framework for the Regulation and Supervision of Non-Interest Banking in Nigeria, circular number BSD/Dir/NIB/01/008 (published on $4^{\text {th }}$ March, 2009).

Central Bank Act 2003.

Constitution of the Federal Republic of Nigeria, 1999.

Nigerian Deposit Insurance Corporation (NDIC) Act 2006.

Nigerian Weekly Law Report (NWLR) 1998 (pt 561).

\section{Cases}

Bashirat Saliu and 2 Other vs. the Provost Kwara State College of Education Ilorin and 2 Others (Unreported) suit no.kws/28m/2006 at Kwara State High Court, Nigeria, ruling delivered $8^{\text {th }}$ May, 2006.

Godwin Sunday Ogboji v. Governor of Central Bank Nigeria \& Ors (2011) [Case File Number: Fhc/Abj/Cs/710/2011] (unreported). 


\section{APPENDIX}

\section{THE PROACTIVE PROPOSALS FOR THE AMENDMENT TO THE CONSTITUTION:}

The proposals are proactive as they forestall future constitutional hindrances to the smooth operation of this enormous tool for inter-faith harmony - IBF. After all, Section 15(1) states that the motto of the Federal Republic of Nigeria shall be "Unity and Faith, Peace and Progress"; therefore IBF should be legally and constitutionally fortified and buttressed as it has proved as a tool for achieving equality and entails economic and scriptural harmony. Furthermore, Section 16(1)(d) provides that:

"The Government should, without prejudice to the right of any person to participate in areas of the economy within the major sector of the economy, protect the right of every citizen to engage in any economic activities outside the major sectors of the economy." 114

This is in line with the fact that IBF is open to all irrespective of religious or other affiliations. The diagnoses of Sections with their lacunae and hypothesized legal remedies are as follows:

Section 1:

(1) This Constitution is supreme and its provisions shall have binding force on the authorities and persons throughout the Federal Republic of Nigeria.

(2) The Federal Republic of Nigeria shall not be governed, nor shall any persons or group of persons take control of the Government of Nigeria or any part thereof, except in accordance with the provisions of this Constitution.

(3) If any other law is inconsistent with the provisions of this Constitution, this Constitution shall prevail, and that other law shall, to the extent of the inconsistency, be void.

Suggested Amendment of sub-section (3):

"If any other law is inconsistent with the provisions of this Constitution, this Constitution shall prevail, and that other law

$\overline{114}$ Section 16(1)(d) Constitution of the Federal Republic of Nigeria 1990 
shall, to the extent of the inconsistency, be void, provided that no provision of the Qur'ān, the Bible, and the Old Testament, which directly affects worship, is made void by this provision."

Section 4(8):

Save as otherwise provided by this Constitution, the exercise of legislative powers by the National Assembly or by a House of Assembly shall be subject to the jurisdiction of courts of law and of judicial tribunals established by law, and accordingly, the National Assembly or a House of Assembly shall not enact any law, that ousts or purports to oust the jurisdiction of a court of law or of a judicial tribunal established by law.

Suggested Amendment of sub-section (8):

"Save as otherwise provided by this Constitution, the exercise of legislative powers by the National Assembly or by a House of Assembly shall be subject to the jurisdiction of courts of law and of judicial tribunals established by law, and accordingly, the National Assembly or a House of Assembly shall not enact any law, that ousts or purports to oust the jurisdiction of a court of law or of a judicial tribunal established by law except through amendments.'

Section 9:

(1) The National Assembly may, subject to the provision of this section, alter any of the provisions of this Constitution.

(2) An Act of the National Assembly for the alteration of this Constitution, not being an Act to which section 8 of this Constitution applies, shall not be passed in either House of the National Assembly unless the proposal is supported by the votes of not less than two-thirds majority of all the members of that House and approved by resolution of the Houses of Assembly of not less than two-thirds of all the States.

Suggested Amendment of sub-section (2):

"An Act of the National Assembly for the alteration of this Constitution, not being an Act to which Section 8 of this Constitution applies, shall not be passed in the House of the National Assembly unless the proposal is supported by the votes of no less than two-thirds majority of all the members of that 
House and approved by resolution of the Houses of Assembly of no less than two-thirds of all the States, provided that the supporting votes of one-third shall suffice in matters relating to the enhancement of national harmony."

Section 10:

The Government of the Federation or of a State shall not adopt any religion as State Religion.

Suggested Amendment of section 10 by creating two sub-sections:

"(1) The Government of the Federation or of a State shall not adopt any religion as State Religion.

(2) Notwithstanding sub-section one, the establishment of any religion based institution does not constitute the adoption of a State Religion."

Section 231:

(3) A person shall not be qualified to hold the office of Chief Justice of Nigeria or a Justice of the Supreme Court, unless he is qualified to practice as a legal practitioner in Nigeria and has been so qualified for a period of not less than fifteen years.

Suggested Amendment of sub-section (3):

"A person shall not be qualified to hold the office of Chief Justice of Nigeria or a Justice of the Supreme Court, unless he is qualified to practice as a legal practitioner in Nigeria and has been so qualified for a period of not less than fifteen years, provided that only justices qualified in Islamic law shall preside over matters involving Islamic Law. "

Section 232:

232. (1) The Supreme Court shall, to the exclusion of any other court, have original jurisdiction in any dispute between the Federation and a state or between states if and in so far as that dispute involves any question (whether of law or fact) on which the existence or extent of a legal right depends.

(2) In addition to the jurisdiction conferred upon it by subsection

(1) of this section, the Supreme Court shall have such original 
jurisdiction as may be conferred upon it by any Act of the National Assembly.

Suggested Amendment of sub-section (2):

(2) In addition to the jurisdiction conferred upon it by subsection

(1) of this Section, the Supreme Court shall have jurisdiction on Banking and Finance matters and such original jurisdiction as may be conferred upon it by any Act of the National Assembly.

Section 238:

(3) A person shall not be qualified to hold the office of a Justice of the Court of Appeal unless he is qualified to practice as a legal practitioner in Nigeria and has been so qualified for a period of not less than twelve years.

Suggested Amendment of sub-section (3):

"(3) A person shall not be qualified to hold the office of a Justice of the Court of Appeal unless he is qualified to practice as a legal practitioner in Nigeria and has been so qualified for a period of not less than twelve years, provided that only justices qualified in Islamic law shall preside over matters involving Islamic Law."

Section 239:

(1) Subject to the provisions of this Constitution, the Court of Appeal shall, to the exclusion of any other court of Law in Nigeria, have original jurisdiction to hear and determine any question as to whether:

(a) any person has been validity elected to the office of President or Vice-President under this Constitution; or

(b) the term of office of the President or Vice-President has ceased; or

(c) the office of President or Vice-President has become vacant.

Suggested Amendment of sub-section (1) by adding a proviso:

"(1) Subject to the provisions of this Constitution, the Court of Appeal shall, to the exclusion of any other court of Law in Nigeria, have original jurisdiction to hear and determine any question as to whether - 
(a) any person has been validity elected to the office of President or Vice-President under this Constitution; or

(b) the term of office of the President or Vice-President has ceased; or

(c) the office of President or Vice-President has become vacant;

provided that only justices qualified in Islamic law shall preside over matters involving Islamic Law."

Section 244:

(1) An appeal shall lie from decisions of a Sharia Court of Appeal to the Court of Appeal as of right in any civil proceedings before the Sharia Court of Appeal with respect to any question of Islamic personal law which the Sharia Court of Appeal is competent to decide.

Suggested Amendment of sub-section (1):

"An appeal shall lie from decisions of a Shariah Court of Appeal to the Court of Appeal as of right in any civil proceedings before the Shariah Court of Appeal with respect to any question of Islamic law which the Shariah Court of Appeal is competent to decide."

Section 244:

(2) Any right of appeal to the Court of Appeal from the decisions of a Sharia Court of Appeal conferred by this section shall be:

(b) exercised in accordance with an Act of the National Assembly and rules of court for the time being in force regulating the powers, practice and procedure of the Court of Appeal.

Suggested Amendment of sub-paragraph (b):

"exercised in accordance with an Act of the National Assembly and rules of court for the time being in force regulating the powers, practice and procedure of the Court of Appeal on Banking and Finance matters."

Section 247: 
(1) For the purpose of exercising any jurisdiction conferred upon it by this Constitution or any other law, the Court of Appeal shall be duly constituted if it consists of not less than three Justices of the Court of Appeal and in the case of appeals from -

(a) a Sharia Court of Appeal if it consists of not less than three Justices of the Court of Appeal learned in Islamic personal law.

Suggested Amendment of sub-paragraph (a):

"a Shariah Court of Appeal if it consists of not less than three Justices of the Court of Appeal learned in Islamic law."

Section 251:

(1) Notwithstanding anything to the contained in this Constitution and in addition to such other jurisdiction as may be conferred upon it by an Act of the National Assembly, the Federal High Court shall have and exercise jurisdiction to the exclusion of any other court in civil causes and matters:

(d) connected with or pertaining to banking, banks, other financial institutions, including any action between one bank and another, any action by or against the Central Bank of Nigeria arising from banking, foreign exchange, coinage, legal tender, bills of exchange, letters of credit, promissory notes and other fiscal measures:

Provided that this paragraph shall not apply to any dispute between an individual customer and his bank in respect of transactions between the individual customer and the bank.

Suggested Amendment of sub-section (1):

(1) Notwithstanding anything contained in this Constitution... provided also that this section does not prevent the vesting of jurisdiction to any other court to determine Islamic Banking and Finance related Civil and Criminal cases.

Section 251:

(1) Notwithstanding anything to the contained in this Constitution and in addition to such other jurisdiction as may be conferred upon it by an Act of the National Assembly, the Federal High Court shall have and exercise jurisdiction to the exclusion of 
any other court in civil causes and matters - (j) bankruptcy and insolvency.

Suggested Amendment of sub-section (1) by adding a proviso:

"provided also that this section does not prevent the vesting of jurisdiction to any other court to determine Islamic Banking and Finance related Civil and Criminal cases."

Sections 256:

(3) A person shall not be qualified to hold the office of a Chief Judge or a Judge of the High Court of the Federation Capital Territory, Abuja unless he is qualified to practice as a legal practitioner in Nigeria and has been so qualified for a period of not less than ten years.

Suggested Amendment of sub-section (3) by adding a proviso:

"provided that only justices qualified in Islamic law shall preside over matters involving Islamic Law."

Section 261:

(1) The appointment of a person to the office of the Grand Kadi of the Sharia Court of Appeal of the Federal Capital Territory, Abuja shall be made by the President on the recommendation of the National Judicial Council, subject to confirmation of such appointment by the Senate.

(2) The appointment of a person to the office of a Kadi of the Sharia Court of Appeal shall be made by the President on the recommendation of the National Judicial Council.

(3) A person shall not be qualified to hold office as Grand Kadi or Kadi of the Sharia Court of Appeal of the Federal Capital Territory, Abuja unless -

(a) he is a legal practitioner in Nigeria and has so qualified for a period of not less than ten years and has obtained a recognized qualification in Islamic law from an institution acceptable to the National Judicial Council; or

(b) he has attended and has obtained a recognized qualification in Islamic law from an institution approved by the National Judicial 
Council and has held the qualification for a period of not less than twelve years; and

(i) he either has considerable experience in the Practice of Islamic law, or

(ii) he is a distinguished scholar of Islamic law.

Suggested Amendment of sub-section (3) by adding a proviso:

"provided that priority should be given to candidates with higher Degrees in Islamic Law."

Section 262:

(1) The Sharia Court of Appeal shall, in addition to such other jurisdiction as may be conferred upon it by an Act of the National Assembly, exercise such appellate and supervisory jurisdiction in civil proceedings involving questions of Islamic personal law.

Suggested Amendment of sub-section (1):

"The Shariah Court of Appeal shall, in addition to such other jurisdiction as may be conferred upon it by an Act of the National Assembly, exercise such appellate and supervisory jurisdiction in civil proceedings involving questions of Islamic law."

Section 262:

(1) The Sharia Court of Appeal shall, in addition to such other jurisdiction as may be conferred upon it by an Act of the National Assembly, exercise such appellate and supervisory jurisdiction in civil proceedings involving questions of Islamic personal law.

(2) For the purpose of subsection (1) of this section, the Sharia Court of Appeal shall be competent to decide -

(a) any question of Islamic personal law regarding a marriage concluded in accordance with that law, including a question relating to the validity or dissolution of such a marriage or a question that depends on such a marriage and relating to family relationship or the guardianship of an infant;

(b) where all the parties to the proceeding are Muslims, any question of Islamic personal law regarding a marriage, including 
the validity or dissolution of that marriage, or regarding family relationship, a foundling or the guardianship of an infant;

(c) any question of Islamic personal law regarding a wakf, gift, will or succession where the endower, donor, testator or deceased person is a Muslim;

(d) any question of Islamic personal law regarding an infant, prodigal or person of unsound mind who is a Muslim or the maintenance or the guardianship of a Muslim who is physically or mentally infirm; or

(e) where all the parties to the proceedings, being Muslims, have requested the court that hears the case in the first instance to determine that case in accordance with Islamic personal law, any other question.

Suggested Amendment of sub-sections (1) and (2) with the creation subparagraph (2)(f):

"(1) The Shariah Court of Appeal shall, in addition to such other jurisdiction as may be conferred upon it by an Act of the National Assembly, exercise such appellate and supervisory jurisdiction in civil proceedings involving questions of Islamic law:

(2) (f) any question of Islamic Banking and Finance is involved."

Sections 264:

"Subject to the provisions of any Act of the National Assembly, the Grand Kadi of the Sharia Court of Appeal of the Federal Capital Territory, Abuja may make rules for regulating the practice and procedure of the Sharia Court of Appeal of the Federal Capital Territory, Abuja."

Suggested Amendment of section 264:

"Subject to the provisions of any Act of the National Assembly, the Grand Kadi of the Shariah Court of Appeal of the Federal Capital Territory, Abuja may make rules for regulating the practice and procedure of the Shariah Court of Appeal of the Federal Capital Territory, Abuja including the practice and procedure on Islamic Banking and Finance matters."

Section 271: 
(3) A person shall not be qualified to hold office of a Judge of a High Court of a State unless he is qualified to practice as a legal practitioner in Nigeria and has been so qualified for a period of not less than ten years.

Suggested Amendment of sub-section (3):

"provided that only justices qualified in Islamic law shall preside over matters involving Islamic Law."

Section 279:

"Subject to provisions of any made by the House of Assembly of the State, the Grand Kadi of the Sharia Court of Appeal of the state may make rules regulating the practice and procedure of the Sharia Court of Appeal."

Suggested Amendment of section (279):

"Subject to provisions of any law made by the House of Assembly of the State, the Grand Kadi of the Sharia Court of Appeal of the state may make rules regulating the practice and procedure of the Shariah Court of Appeal including the practice and procedure on Islamic Banking and Finance matters."

Section 288:

"(1) In exercising his powers under the foregoing provisions of this Chapter in respect of appointments to the offices of Justices of the Supreme court and Justices of the Court of Appeal, the President shall have regard to the need to ensure that there are among the holders of such offices persons learned in Islamic personal law and persons learned in Customary law."

(2) For the purposes of subsection (1) of this section:

"(a) a person shall be deemed to be learned in Islamic personal law if he is a legal practitioner in Nigeria and has been so qualified for a period of not less than fifteen years in the case of a Justice of the Supreme Court or not less than twelve years in the case of a Justice of the Court of Appeal and has in either case obtained a recognized qualification in Islamic law from an institution acceptable to the national Judicial Council assert that President shall have regard to the need to ensure that there are 
among the holders of the offices of Justices of FCA and the SC, persons learned in Islamic personal law."

Suggested Amendments of sub-sections (1) and (2):

“(1) In exercising his powers under the foregoing provisions of this Chapter in respect of appointments to the offices of Justices of the Supreme court and Justices of the Court of Appeal, the President shall have regard to the need to ensure that there are among the holders of such offices persons learned in Islamic law and persons learned in Customary law.

(2) For the purposes of subsection (1) of this section -

(a) a person shall be deemed to be learned in Islamic law if he is a legal practitioner in Nigeria and has been so qualified for a period of not less than fifteen years in the case of a Justice of the Supreme Court or not less than twelve years in the case of a Justice of the Court of Appeal and has in either case obtained a recognized qualification in Islamic law from an institution acceptable to the national Judicial Council assert that President shall have regard to the need to ensure that there are among the holders of the offices of Justices of FCA and the SC, persons learned in Islamic law." 